\title{
A model for microbial phosphorus cycling in bioturbated marine sediments: significance for phosphorus burial in the early Paleozoic
}

\author{
Andrew W. Dale ${ }^{\mathrm{a}}$, Richard A. Boyle ${ }^{\mathrm{b}}$, Timothy M. Lenton ${ }^{\mathrm{c}}$, Ellery D. Ingall ${ }^{\mathrm{d}}$, Klaus \\ Wallmann ${ }^{\mathrm{a}}$ \\ ${ }^{a}$ GEOMAR Helmholtz Centre for Ocean Research Kiel, Wischhofstrasse 1-3, 24148 Kiel, \\ Germany \\ ${ }^{\mathrm{b}}$ Institute of Biology and Nordic Centre for Earth Evolution, University of Southern \\ Denmark, Campusvej 55, 5230 Odense M, Odense, Denmark \\ ${ }^{c}$ Earth System Science group, College of Life and Environmental Sciences, University of \\ Exeter, Laver Building (Level 7), North Park Road, Exeter EX4 4QE, UK \\ ${ }^{\mathrm{d}}$ School of Earth and Atmospheric Sciences, Georgia Institute of Technology, Atlanta, \\ Georgia 30332-0340, USA \\ Corresponding author: A. W. Dale (adale@geomar.de)

\section{Key points} \\ - An empirical diagenetic model includes redox-dependent $\mathrm{P}$ storage by microorganisms \\ - Sediment mixing and burrowing by animals strongly enhances P burial \\ - Supporting evidence for a decrease in oceanic P inventory in the early Paleozoic
}




\section{Abstract}

32 A diagenetic model is used to simulate the diagenesis and burial of particulate organic carbon $\left(\mathrm{C}_{\text {org }}\right)$ and phosphorus $(\mathrm{P})$ in marine sediments underlying anoxic versus oxic bottom waters. The latter are physically mixed by animals moving through the surface sediment (bioturbation) and ventilated by burrowing, tube-dwelling organisms (bioirrigation). The model is constrained using an empirical database including burial ratios of $\mathrm{C}_{\text {org }}$ with respect to organic $\mathrm{P}\left(\mathrm{C}_{\text {org }}: \mathrm{P}_{\text {org }}\right)$ and total reactive $\mathrm{P}$ $\left(\mathrm{C}_{\text {org }}: \mathrm{P}_{\text {reac }}\right)$, burial efficiencies of $\mathrm{C}_{\text {org }}$ and $\mathrm{P}_{\text {org }}$, and inorganic carbon-to-phosphorus regeneration ratios. If $\mathrm{P}_{\text {org }}$ is preferentially mineralized relative to $\mathrm{C}_{\text {org }}$ during aerobic respiration, as many previous studies suggest, then the simulated $\mathrm{P}_{\text {org }}$ pool is found to be completely depleted. A modified model that incorporates the redox-dependent microbial synthesis of polyphosphates and $\mathrm{P}_{\text {org }}$ (termed the microbial $\mathrm{P}$ pump) allows preferential mineralization of the bulk $\mathrm{P}_{\text {org }}$ pool relative to $\mathrm{C}_{\text {org }}$ during both aerobic and anaerobic respiration and is consistent with the database. Results with this model show that $\mathrm{P}$ burial is strongly enhanced in sediments hosting fauna. Animals mix highly labile $\mathrm{P}_{\text {org }}$ away from the aerobic sediment layers where mineralization rates are highest, thereby mitigating diffusive $\mathrm{PO}_{4}{ }^{3-}$ fluxes to the bottom water. They also expand the redox niche where microbial $\mathrm{P}$ uptake occurs. The model was applied to a hypothetical shelf setting in the early Paleozoic; a time of the first radiation of benthic fauna. Results show that even shallow bioturbation at that time may have had a significant impact on P burial; an effect that increases with subsequent deeper bioturbation. Our model provides support for a recent study that proposed that faunal radiation in ocean sediments led to enhanced $\mathrm{P}$ burial and, possibly, a stabilization of atmospheric $\mathrm{O}_{2}$ levels. The results also help to explain $\mathrm{C}_{\text {org }}: \mathrm{P}_{\text {org }}$ ratios in the geological record and the persistence of $\mathrm{P}_{\text {org }}$ in ancient marine sediments. 


\section{Introduction}

53

54

55

56

57

Permanent burial of phosphorus $(\mathrm{P})$ in continental margin sediments is a major control on the marine P inventory, primary productivity and possibly interglacial $\mathrm{CO}_{2}$ concentrations (e.g. Broecker, 1982; Wallmann, 2014). On Myr time scales, P burial exerts a strong, if not dominating, influence on atmospheric $\mathrm{O}_{2}$ levels (Van Cappellen and Ingall, 1996; Lenton and Watson, 2000; Boyle et al., 2014). Diagenetic transformations of $P$ and the factors controlling $P$ burial are thus intensively studied (reviewed by Benitez-Nelson, 2000; Paytan and McLaughlin, 2007; Slomp, 2011; Ruttenberg, 2014).

Particulate organic $\mathrm{P}\left(\mathrm{P}_{\mathrm{org}}\right)$ comprises more than $90 \%$ of $\mathrm{P}$ that rains to the seafloor (Delaney, 1998). Phosphate $\left(\mathrm{PO}_{4}{ }^{3-}\right)$ that is solubilized from $\mathrm{P}_{\text {org }}$ in the sediments can be sequestered into authigenic mineral phases, mainly as carbonate fluorapatite (CFA) and $\mathrm{P}$ bound or adsorbed to iron oxyhydroxides (FeP) (Berner et al., 1993). These transformations, more generally described as 'sink switching, increase the overall benthic retention efficiency of P (Ruttenberg and Berner, 1993; Anderson et al., 2001). Observations from the North Atlantic suggest that sink-switching is enhanced in sediments that are bioturbated, that is, reworked by infaunal deposit and detritus feeders (Slomp et al., 1996). The sedimentary retention capacity of $P$ further appears to be sensitive to the ambient redox conditions (Algeo and Ingall, 2007). For example, FeP content tends to be lower under anoxic bottom waters due to reduced ferrous iron oxidation and co-sequestration of P (Sundby et al., 1992; Jensen et al., 1995; McManus et al., 1997). CFA content may be higher under these conditions, especially in modern oxygen minimum zones where phosphorites may form (Papineau, 2010).

The impact of oxygen levels on $\mathrm{P}_{\text {org }}$ burial is less well understood. Data on $\mathrm{P}_{\text {org }}$ burial efficiencies (PBE) are scarce, yet point toward lower values under anoxic versus oxic bottom waters, that is, preferential mineralization of $\mathrm{P}_{\text {org }}$ in anoxic settings. This trend is opposite to the organic carbon burial efficiency (CBE), which is apparently high under anoxic bottom waters and low under oxic waters (see Table 1 and further discussion by Burdige, 2007). It thus follows that molar organic carbon to phosphorus ratios $\left(\mathrm{C}_{\text {org }}: \mathrm{P}_{\text {org }}\right)$ in laminated anoxic facies commonly exceed the Redfield ratio (106:1), whereas bioturbated sediments have ratios that are around Redfield or lower (Table 1). This difference is maintained, although less pronounced, for the ratio of $\mathrm{C}_{\text {org }}$ to reactive phosphorus $\left(\mathrm{P}_{\text {reac }}=\right.$ $\left.\mathrm{P}_{\text {org }}+\mathrm{FeP}+\mathrm{CFA}\right)$. Consistent with these findings, the inorganic carbon-to-phosphorus regeneration ratio derived from in situ flux measurements, $(\mathrm{C}: \mathrm{P})_{\mathrm{REG}}$, is often above Redfield in oxic settings and below it in sediments underlying intermittently or permanently oxygen-deficient waters (Table 1). Consequently, C:P burial ratios are used as a proxy for bottom water redox conditions and biological productivity in the paleo-ocean (Ingall and Jahnke, 1994; Slomp and Van Cappellen, 2007).

The factors that control the $\mathrm{C}_{\text {org }}: \mathrm{P}_{\text {org }}$ ratio are unclear and controversial (Van Cappellen and Ingall, 1996; 1997; Colman et al., 1997). Basic questions remain, such as the extent of preferential 
mineralization of $\mathrm{P}_{\text {org }}$ relative to $\mathrm{C}_{\text {org }}$ under oxic versus anoxic conditions (Colman and Holland, 2000 ), not least because the kinetics of $\mathrm{C}_{\text {org }}$ and $\mathrm{P}_{\text {org }}$ mineralization are very poorly understood. Some workers have proposed that microbial sequestration of $\mathrm{P}$ can help to explain redox-dependent $\mathrm{C}_{\text {org }}: \mathrm{P}_{\text {org }}$ burial ratios (Ingall and Van Cappellen, 1990; Ingall et al., 1993; Ingall and Jahnke, 1997; Sannigrahi and Ingall, 2005; Diaz et al., 2008; Goldhammer et al., 2010; Diaz et al., 2012). Many genera of bacteria are known to accumulate and store $\mathrm{P}$ as polyphosphate under aerobic and nitrogenous conditions (Shapiro, 1967; Gächter and Meyer, 1993; Davelaar, 1993; Kulaev and Kulakovskaya, 2000). Polyphosphates are long chains of orthophosphate units linked by high energy phosphoanhydride bonds (Gächter and Meyer, 1993). Experimental observations indeed confirm that biologically associated P is higher in oxidized sediments (Gächter et al., 1988; Aller, 1994). It has been suggested that organic $\mathrm{P}$ biomolecules synthesized under oxic conditions, possibly via polyphosphate intermediates, are converted into nearly non-metabolizable organic $\mathrm{P}$ such as some phosphate esters and phosphonates that are subsequently permanently buried (Ingall et al., 1990; Berner et al., 1993; Ingall et al., 1993; Ingall and Jahnke, 1994; Van Cappellen and Ingall, 1994; Ingall and Jahnke, 1997). This would constitute a microbially-mediated P sink that is more efficient under oxic bottom waters, favoring an increase in $\mathrm{P}_{\text {org }}$ burial relative to $\mathrm{C}_{\text {org }}$ (i.e. low $\mathrm{C}_{\text {org }}: \mathrm{P}_{\text {org }}$ burial ratios, Table 1). Refractive microbial P compounds could also help to explain the puzzling persistence of $\mathrm{P}_{\text {org }}$ in ancient marine sediments (Ruttenberg, 2014).

In this study, we aim to unify these different perspectives of $\mathrm{P}$ cycling using a diagenetic model for continental margin sediments, specifically, a shallow marine shelf with a water depth of $\sim 100 \mathrm{~m}$. The observational database in Table 1 is used to (i) ascertain the extent of preferential mineralization of $\mathrm{P}_{\text {org }}$ relative to $\mathrm{C}_{\text {org }}$ in oxic and anoxic sediments, and (ii) quantify the impact of sediment mixing by animals on P burial. Both of these are open questions with an important bearing on the interpretation of the sedimentary record.

Our interest in the role of fauna on $\mathrm{P}$ burial stems from the radiation of deposit feeders and burrowers in the terminal Ediacaran to early Paleozoic (ca. 542 - 420 Ma). This may have occurred against a backdrop of variability in ocean redox conditions, with conceivable impacts on, and geochemical feedbacks with, the spread of early animals (Canfield et al., 2007; Shen et al., 2008; Butterfield, 2009; Johnston et al., 2012; Lyons et al., 2012; Och and Shields-Zhou, 2012). One possible feedback loop relates to the argument that the onset of bioturbation at this time led to enhanced burial of $\mathrm{P}$ and stabilization of atmospheric $\mathrm{O}_{2}$ levels (Boyle et al., 2014). The major control on sedimentary $\mathrm{P}$ burial in global models of ancient oceans is traditionally assumed to be the $\mathrm{O}_{2}$ availability rather than bioturbation per se, with any mechanistic linkage with bioturbation being merely implicit (Van Cappellen and Ingall, 1994; 1996; Lenton and Watson, 2000). The validity of this assumption is tested 
here with the diagenetic model. We find that indwelling fauna, in combination with microbial $\mathrm{P}$ synthesis, would have strongly enhanced P burial in the early Palaeozoic Era.

\section{Model}

\subsection{Architecture and application}

A vertically-resolved 1-D model is used to investigate the coupled biogeochemical cycling of $\mathrm{C}, \mathrm{N}, \mathrm{P}$, $\mathrm{Mn}, \mathrm{Fe}$ and $\mathrm{S}$ in the uppermost meter of fine-grained continental shelf sediments (ca. $100 \mathrm{~m}$ water depth). Full details of the model can be found in the Supplementary Material and in Dale et al. (2015a). For the present study, we limit the biogeochemical model description to the previously unpublished P cycle. Key model boundary conditions and parameters are listed in Table 2.

A total of 13 solutes and 17 solid species are considered in the model. Particulate matter is transported dynamically through the sediment column by accumulation (burial) and bioturbation. Solutes are transported by molecular diffusion and bioirrigation. The coupling of biogeochemistry and transport is summarized by the following generic mass-conservation equations (Berner, 1980; Boudreau, 1997):

$\varphi \frac{\partial C_{a}}{\partial t}=\frac{\partial}{\partial z}\left(\varphi D \frac{\partial C_{a}(z, t)}{\partial z}\right)-\frac{\partial \varphi(L) \omega_{a c c} C_{a}}{\partial z}+\alpha(0) \cdot \gamma \cdot \exp \left(-\frac{z}{z_{b i o}}\right) \varphi\left(C_{a}(0)-C_{a}\right)+\Sigma \varphi R$

$(1-\varphi) \frac{\partial C_{s}}{\partial t}=\frac{\partial}{\partial z}\left((1-\varphi) D_{b}(0) \cdot \exp \left(-\frac{z^{2}}{2 \cdot z_{b t}^{2}}\right) \frac{\partial C_{s}}{\partial z}\right)-\frac{\partial(1-\varphi(L)) \cdot \omega_{a c c} \cdot C_{S}}{\partial z}+\Sigma(1-\varphi) R$

where $C_{a}$ and $C_{s}$ are the time- and depth-dependent concentrations of solutes in $\mathrm{mmol} \mathrm{cm}$ (of pore water) and particulate species in weight percent of dry sediment $(\%)$, respectively, $z(\mathrm{~cm})$ denotes depth in the sediment, $\varphi$ is porosity, $\omega_{\text {acc }}\left(\mathrm{cm} \mathrm{yr}^{-1}\right)$ is the sedimentation rate, $D\left(\mathrm{~cm}^{2} \mathrm{yr}^{-1}\right)$ is the molecular diffusion coefficient, and $\Sigma R$ is the sum of the rate of change of concentration due to biogeochemical reactions. Constitutive equations describing the depth dependency of transport parameters are provided in Table S1, and the complete list of biogeochemical reactions, rate expressions and parameters are given in Table S2 to S5. In this study, model results represent steady state simulations, that is, where concentrations are invariable with time $(\partial \mathrm{C} / \partial \mathrm{t}=0)$.

The third term on the right-hand-side of Eq. (1a) describes the exponential decrease of bioirrigation with sediment depth. Bioirrigation is the non-local exchange of seawater with burrow water by the pumping activity of tube-dwelling animals (Aller and Aller, 1992). Mathematically, the process is described using the parameters $\alpha(0)\left(\mathrm{y}^{-1}\right)$ and $C_{a}(0)$, which are the maximum bioirrigation coefficient 
(under oxic bottom waters) and solute concentration at the sediment-water interface, respectively. $z_{\text {bio }}$ (cm) is the attenuation coefficient that parameterizes the depth to which burrows extend below the sediment surface. The dimensionless parameter $\gamma$ is a scaling parameter for ferrous iron to reflect rapid oxidation on burrow walls (see Dale et al., 2015a).

Bioturbation, the first term on the right-hand-side of Eq. (1b), is treated as biodiffusion, analogous to molecular diffusion, using a Gaussian function to describe the decrease in sediment mixing with sediment depth (Boudreau, 1996). The maximum rate of particle reworking in the surface mixed layer is defined by the bioturbation enhanced diffusion coefficient, $D_{b}(0)\left(\mathrm{cm}^{2} \mathrm{yr}^{-1}\right)$. The parameter $z_{b t}(\mathrm{~cm})$ defines the depth at which bioturbation intensity is half of $D_{b}(0)$, according to the Gaussian decrease in bioturbation intensity. A relation between $D_{b}(0)$ and $z_{b t}$ has, to our knowledge, not been demonstrated empirically, and these parameters are independent of one another.

Our treatment of biodiffusion can be viewed as reverse conveyor-belt feeding, i.e. downward transport of particles (reviewed by Burdige, 2006; Meysman et al., 2003). It is also a local process, because it mixes sediment between adjacent layers. However, under natural conditions, most modes of sediment transport adhere to non-local exchange formalisms, that is, transport of material between non-adjacent sediment layers (Meysman et al., 2003). Non-local sediment mixing can occur both upwards by conveyor-belt (head-down) feeding and downwards (e.g. ingestion at surface, egestion at depth). Non-local conveyor-belt feeding tends to retain radiotracers such as ${ }^{210} \mathrm{~Pb}$ in the surface mixed layer, and steady-state tracer profiles resulting from this type of transport tend to resemble those resulting from the biodiffusion model (Boudreau, 1986). Non-local reverse conveyor-belt feeding, on the other hand, gives rise to subsurface maxima in tracer profiles (Smith et al., 1986). Although the exact pattern of tracer distribution will depend on the specific mixing mechanism, each type of feeding behavior will lead to a mixing of aged and fresh organic matter within the bioturbated. In this paper, we adopt the biodiffusion model because it has been proven to be a robust empirical model for sediment mixing and is straightforward to solve numerically. More complex treatments have been developed elsewhere (Robbins, 1986; Boudreau, 1986).

The value of $z_{b t}$ is set to $3 \mathrm{~cm}$, to reflect a mean mixed layer thickness in the modern ocean of 5 to 10 $\mathrm{cm}$ (Boudreau, 1997; Teal et al., 2008). The parameters $z_{b t}$ and $z_{b i o}$ are deemed to be independent of one another since the ecology of sediment 'bulldozers' and irrigators is different. Here, we simply set $z_{\text {bio }}$ to $2 \mathrm{~cm}$ so that the irrigation depth is similar to the bioturbation depth (Archer et al., 2002). It is important to note that these parameters correspond to the sediment mixed layer where reworking or bulldozing by animals is sufficiently intense to homogenize the sediment (Tarhan et al., 2015). In contrast, burrows may extend many decimeters below the mixed layer and impact biogeochemical cycling there. The ghost shrimp N. californiensis, for example, can enhance denitrification by pumping seawater nitrate into deep sediment layers (Bertics et al., 2010). In this paper, we do not 
consider deep irrigation because it is in all likelihood much weaker than surface irrigation (Fossing et al., 2000). Our focus on the surface sediment will facilitate comparisons with the early Paleozoic scenarios where the maximum burrow depth is limited to a few $\mathrm{cm}$ (Tarhan et al., 2015). The sensitivity of the model to bioturbation and bioirrigation is tested later.

The model is applied across a range of bottom water dissolved $\mathrm{O}_{2}$ concentrations from anoxic ( 0.1 $\mu \mathrm{M})$ to oxic $(150 \mu \mathrm{M})$. The former threshold is not strictly anoxic, but instead represents the microaerobic conditions that exist within some 'anoxic' oxygen minimum zones such as in the Eastern South Pacific Ocean (Thamdrup et al., 2012). Under oxic conditions, the parameters $D_{b}(0)$ and $\alpha(0)$ take values of $28 \mathrm{~cm}^{2} \mathrm{yr}^{-1}$ and $465 \mathrm{y}^{-1}$, respectively (Supplement). They are allowed to decrease gradually toward zero if $\mathrm{O}_{2}$ drops below a $20 \mu \mathrm{M}$ threshold. At this concentration, a decrease in species richness and bioirrigation has been observed (Levin and Gage, 1998; Dale et al., 2013) with surface deposit feeders dominating over burrowing macrofauna (Middelburg and Levin, 2009).

We begin by focusing on modern sediments, for which data are relatively abundant, in order to parameterize the $\mathrm{P}$ cycle. To avoid the risk of being too site-specific, $\mathrm{P}$ turnover is mainly constrained by the data in Table 1 that originate from a wide range of marine settings. In that sense, the model is more emblematic of an average shallow continental margin setting. Parameterization of transport and biogeochemical processes draws from a large body of previous empirical studies from shelf environments (Supplementary Material). In particular, this includes realistic organic matter and iron fluxes to the seafloor, organic matter reactivity, reaction rate constants, sedimentation rates, and bioturbation and bioirrigation intensities. Most of these are taken directly from the shelf scenario in Dale et al. (2015a) that is confirmed against a global database of dissolved iron fluxes. Only a minimal amount of additional parameter tuning has been used for organic matter degradation as described below. The model is then applied to the early Paleozoic shelf environment (ca. $542-420$ Ma) by altering the boundary conditions accordingly. We define sediments underlying anoxic waters as 'anoxic' whereas bioturbated sediments under oxic waters are termed 'oxic', whilst noting that the latter quickly turn anoxic and anaerobic below the thin surface oxidized layer $(<\mathrm{ca} .1 \mathrm{~cm}$, Glud et al., 2008 and Results).

\subsection{Phosphorus biogeochemistry}

The $\mathrm{P}$ cycle initially centers on three particulate species (Fig. 1): organic $\mathrm{P}\left(\mathrm{P}_{\mathrm{org}}\right)$, iron-associated $\mathrm{P}$ $(\mathrm{FeP})$ and carbonate fluorapatite (CFA). Dissolved P takes the form of inorganic orthophosphate $\left(\mathrm{PO}_{4}{ }^{3-}\right)$. The $\mathrm{P}$ model is similar to previous applications (Van Cappellen and Berner, 1988; Reed et al., 2011; Kraal et al., 2012) and, like these other models, highly simplifies the representation of P cycling in sediments, especially with regard to authigenic P mineral formation. However, the main diagenetic 
pathways are included. Our model structure differs from the other studies by the inclusion of P uptake 222 by microorganisms (Section 3.3), plus a more realistic description of organic matter degradation 223 kinetics. P concentrations are reported in $\mu \mathrm{mol} \mathrm{g} \mathrm{g}^{-1}$ of $\mathrm{P}\left(0.01 \mathrm{wt} . \%=3.23 \mu \mathrm{mol} \mathrm{g}{ }^{-1}\right)$.

Mineralization of deposited organic matter, chemically defined as $\mathrm{CN}_{r N C} \mathrm{P}_{r P C}$, drives all diagenetic reactions that take place in the model. Parameters $r_{N C}$ and $r_{P C}$ are the (Redfield) atomic ratios of particulate organic nitrogen and phosphorus to carbon (Table 2). Dissolution of organic nitrogen and phosphorus is coupled to the rate of $\mathrm{C}_{\text {org }}$ mineralization. $\mathrm{C}_{\text {org }}$ is oxidized by several pathways; aerobic respiration, nitrate and nitrite reduction (denitrification), manganese oxide reduction, dissimilatory iron reduction, sulfate reduction and methanogenesis in that order $\left(\mathrm{R}_{1}\right.$ to $\mathrm{R}_{7}$, Table $\left.\mathrm{S} 4\right)$. The kinetics of $\mathrm{C}_{\text {org }}$ mineralization is described using continuum kinetics, where the rate constant for $\mathrm{C}_{\text {org }}$ degradation is time dependent (Middelburg, 1989; Boudreau and Ruddick, 1991):

In this expression, $a(\mathrm{yr})$ is the average lifetime of the reactive components and $v$ (dimensionless) is the distribution of $\mathrm{C}_{\mathrm{org}}$ reactivity. Low $v$ values indicate that $\mathrm{C}_{\mathrm{org}}$ is dominated by refractory components, whereas higher values correspond to a more even distribution of reactive types. Similarly, $\mathrm{C}_{\text {org }}$ characterized by low $a$ will be rapidly degraded whereas high $a$ implies less reactive material that is more likely to be buried to deeper sediments. Reactive continuum-type models predict a more realistic profile of $\mathrm{C}_{\text {org }}$ reactivity with sediment depth than those based on 'multi-G' kinetics. The latter require a somewhat arbitrary number of discrete $C_{\text {org }}$ fractions, or ' $G$ ', to be assigned individual rate constants that are poorly defined at the global scale (Boudreau and Ruddick, 1991). The choice of degradation kinetics is important because it determines the sediment redox structure and the depth at which $\mathrm{P}$ fractions are dissolved or precipitated and, hence, phosphate fluxes across the sediment-water interface. However, continuum models are difficult to apply to bioturbated sediments since the age and reactivity of organic matter within the bioturbated zone tend to be poorly constrained (Boudreau and Ruddick, 1991; Middelburg, 1989). Ages of radioactive tracers within the bioturbated zone depend not only on the burial velocity and bioturbation rate but also on the decay rate of the tracer itself (Meile and Van Cappellen, 2005).

We used a previous approach (Dale et al., 2015a) that calculates discrete $\mathrm{C}_{\text {org }}$ fractions from the continuum parameters $a$ and $v$ that, when summed together, give the same $\mathrm{C}_{\text {org }}$ reactivity profile as the continuum model. More accurate results are produced as the number of defined $\mathrm{C}_{\text {org }}$ fractions increases. Fourteen fractions were found to give an excellent agreement with the continuum model (Dale et al., 2015a), using an initial parameterization of $a\left(3 \times 10^{-4} \mathrm{yr}\right)$ and $v(0.125)$ constrained from oxic degradation experiments with fresh phytoplankton (Boudreau et al., 2008). The rate of $\mathrm{P}_{\text {org }}$ mineralization for each pathway is initially determined as: 
256 where RPOC is the total rate of POC degradation and $\psi$ represents the sum of oxidant limitation and 257 inhibition terms (see Supplement). Later, the rate of $\mathrm{P}_{\text {org }}$ mineralization will be adjusted depending on 258 whether organic matter is respired aerobically or anaerobically. Organic phosphorus is mineralized to 259 dissolved $\mathrm{PO}_{4}{ }^{3-}$.

260 Four reactive fractions of particulate iron oxides were defined according to the classification scheme 261 based on wet chemical extractions (Canfield et al., 1992; Poulton et al., 2004). These are defined as 262 highly reactive $\left(\mathrm{Fe}_{\mathrm{HR}}\right.$, e.g. nano-geothite), moderately reactive ( $\mathrm{Fe}_{\mathrm{MR}}$, e.g. goethite and hematite), and 263 poorly reactive ( $\mathrm{Fe}_{\mathrm{PR}}$, e.g. iron silicates). $\mathrm{Fe}_{\mathrm{HR}}, \mathrm{Fe}_{\mathrm{MR}}$ and $\mathrm{Fe}_{\mathrm{PR}}$ are all dissolvable by sulfide, but at 264 different rates (see Supplementary Material). The model also includes detrital (unreactive) iron.

265 Reactions that couple the $\mathrm{Fe}$ and $\mathrm{P}$ cycle are the dissolution of $\mathrm{Fe}_{\mathrm{HR}}$ by dissimilatory iron reduction $266\left(\mathrm{R}_{5}\right)$, authigenic precipitation of $\mathrm{Fe}_{\mathrm{HR}}$ via aerobic and anaerobic oxidation of ferrous iron $\left(\mathrm{R}_{13}, \mathrm{R}_{14}\right.$, $267 \mathrm{R}_{24}$ ), reductive dissolution of $\mathrm{Fe}_{\mathrm{HR}}$ and $\mathrm{Fe}_{\mathrm{MR}}$ by sulfide $\left(\mathrm{R}_{26}\right)$, and the ageing and crystallization of $268 \mathrm{Fe}_{\mathrm{HR}}$ into more stable $\mathrm{Fe}_{\mathrm{MR}}$ phases $\left(\mathrm{R}_{28}\right)$. These are given as (see Supplement for more details):

$\mathrm{R}_{5}: \quad \mathrm{CN}_{r N C} \mathrm{P}_{r P C}+4 \mathrm{Fe}_{\mathrm{HR}}+4 \theta_{\mathrm{HR}} \rightarrow 4 \mathrm{Fe}^{2+}+\mathrm{TCO}_{2}+r_{N C} \mathrm{NH}_{4}{ }^{+}+\left(4 \theta_{\mathrm{HR}}+r_{P C}\right) \mathrm{PO}_{4}{ }^{3-}$

$\mathrm{R}_{13}: \quad \mathrm{Fe}^{2+}+0.25 \mathrm{O}_{2}+1 / \varepsilon_{\text {aut }} \cdot \mathrm{PO}_{4}{ }^{3-} \rightarrow \mathrm{Fe}_{\mathrm{HR}}+1 / \varepsilon_{\text {aut }} \cdot \mathrm{FeP}_{\mathrm{HR}}$

$\mathrm{R}_{14}: \quad \mathrm{Fe}^{2+}+0.2 \mathrm{NO}_{3}^{-}+1 / \varepsilon_{\text {aut }} \cdot \mathrm{PO}_{4}^{3-} \rightarrow 0.1 \mathrm{~N}_{2}+\mathrm{Fe}_{\mathrm{HR}}+1 / \varepsilon_{\text {aut }} \cdot \mathrm{FeP}_{\mathrm{HR}}$

$\mathrm{R}_{24}: \quad \mathrm{Fe}^{2+}+\mathrm{Mn}_{j}+1 / \varepsilon_{\text {aut }} \cdot \mathrm{PO}_{4}^{3-} \rightarrow \mathrm{Mn}^{2+}+\mathrm{Fe}_{\mathrm{HR}}+1 / \varepsilon_{\text {aut }} \cdot \mathrm{FeP}_{\mathrm{HR}}$

for $j=\mathrm{HR}, \mathrm{MR}$

$\mathrm{R}_{26}: \quad \mathrm{Fe}_{j}+\theta_{j}+0.5 \mathrm{H}_{2} \mathrm{~S} \rightarrow \mathrm{Fe}^{2+}+0.5 \mathrm{~S}^{0}+\theta_{j} \mathrm{PO}_{4}{ }^{3-}$

for $j=\mathrm{HR}, \mathrm{MR}$

$\mathrm{R}_{28}: \quad \mathrm{Fe}_{\mathrm{HR}}+\theta_{\mathrm{HR}}+1 / \varepsilon_{\text {age }} \cdot \mathrm{PO}_{4}{ }^{3-} \rightarrow \mathrm{Fe}_{\mathrm{MR}}+\theta_{\mathrm{HR}} \mathrm{PO}_{4}{ }^{3-}+1 / \varepsilon_{\text {age }} \cdot \mathrm{FeP}_{\mathrm{MR}}$

Detrital P bound within highly crystalline iron fractions and other minerals is not considered in the model. The iron module also includes precipitation of iron sulfide minerals, although without associated P turnover (Krom and Berner, 1980).

The change in $\mathrm{FeP}$ content is calculated using the particulate fraction of $\mathrm{P}$ to $\mathrm{Fe}(\theta$, mol $\mathrm{P} / \mathrm{mol} \mathrm{Fe})$ and/or Fe:P enrichment ratios ( $\varepsilon$, mol Fe / mol P) (Dale et al., 2013). The capacity of poorly crystalline iron oxides to sequester large amounts of ambient $\mathrm{PO}_{4}{ }^{3-}$ is well recognized (Torrent et al., 1992; Slomp et al., 1996; Anschutz et al., 1998; Feely et al., 1998). The Fe:P ratio in amorphous iron oxides in surface sediments, principally nano-particulate goethite, seems to be constant at around 10 
285 (Sundby et al., 1992; Jensen and Thamdrup, 1993; Slomp et al., 1996; Anschutz et al., 1998; van der 286 Zee et al., 2003). Hence, we take this value for $\varepsilon_{\text {aut }}$ in $\mathrm{R}_{13}, \mathrm{R}_{14}$ and $\mathrm{R}_{24}$. The rate expressions for these reactions include a rate-limiting term that slows down the rate of $\mathrm{PO}_{4}{ }^{3-}$ uptake into $\mathrm{Fe}_{\mathrm{HR}}$ if $\mathrm{PO}_{4}{ }^{3-}$ concentrations are diminished to low levels (Table S5). Authigenic $\mathrm{Fe}_{\mathrm{HR}}$ can therefore have a Fe:P ratio that is higher than 10 if the ambient $\mathrm{PO}_{4}{ }^{3-}$ concentration is very low at the site where $\mathrm{Fe}^{2+}$ crystallizes from solution.

The FeP pool can be preserved by ageing processes (Lijklema, 1980; Borggaard, 1991). However, crystallization decreases the mineral surface area and the sorptive capacity of $\mathrm{PO}_{4}{ }^{3-}$, releasing $\mathrm{PO}_{4}{ }^{3-}$ to solution (Houben, 2003). Based on observations by Poulton and Canfield (2006), the Fe:P ratio of recrystallized iron, $\varepsilon_{a g e}$, is set to be a factor of 4 higher than for the highly reactive fractions (40).

The only allochthonous source of $\mathrm{FeP}$ is associated with the flux of $\mathrm{Fe}_{\mathrm{HR}}$, which requires knowledge of the Fe:P atomic ratio in iron oxides deposited on the shelf $\left(\varepsilon_{\text {all }}\right)$. Most reactive iron oxide deposited there originates as colloidal coagulates formed in the low salinity region in estuaries (Boyle et al., 1977). The fraction of $\mathrm{P}$ that is adsorbed to these colloids decreases with increasing salinity, $\mathrm{pH}$ and decreasing concentrations of suspended particulate matter (Boyle et al., 1977; Bale and Morris, 1981; Lebo, 1991; Spiteri et al., 2008). Jordan et al. (2008) reported an increase in the Fe:P ratio in the Patuxent River estuary from ca. 9 in the freshwater end member to ca. 13 at a salinity of 7. Measurements in the St. Lawrence Estuary show a Fe:P ratio of around 18 to 23 close to the sea water end member (Lucotte and D'Anglejan, 1983). Further P depletion in iron oxides can occur if the suspended material has first been subjected to reductive dissolution in the estuarine sediment (Berner and Rao, 1994). These studies demonstrate a wide range of the Fe:P ratio in deposited iron oxides. For our model we assume that $\varepsilon_{a l l}=25$, that is, depleted in $\mathrm{P}$ relative to authigenic $\mathrm{Fe}_{\mathrm{HR}}$.

Finally, the model includes the irreversible crystallization of dispersed CFA directly from porewater $\mathrm{PO}_{4}{ }^{3-}$ without a precursor phase (Froelich et al., 1988; Van Cappellen and Berner, 1988). We assume the following idealized stoichiometry (Froelich et al., 1988):

$10 \mathrm{Ca}^{2+}+(6-x) \mathrm{PO}_{4}{ }^{3-}+x \mathrm{CO}_{3}{ }^{2-}+(2+x) \mathrm{F}^{-} \rightarrow \mathrm{Ca}_{10}\left(\mathrm{PO}_{4}\right)_{6-x}\left(\mathrm{CO}_{3}\right)_{x} \mathrm{~F}_{2+x}$

311 where a value of $x=0.26$ is assigned, such that the F:P ratio in the crystallized apatite is 0.39 312 (Froelich et al., 1988; Van Cappellen and Berner, 1988). Changes in the extent of substitution of 313 carbonate and fluoride due to factors such as the pore fluid composition are ignored (Froelich et al., 314 1988). The rate of apatite precipitation is described as a kinetically-controlled process. The rate limiting factor is the concentration of $\mathrm{PO}_{4}{ }^{3-}$ in excess of the concentration in thermodynamic equilibrium with CFA, $\mathrm{C}_{\mathrm{eq}}$ (Van Cappellen and Berner, 1988). Apatite formation is inhibited if $\mathrm{PO}_{4}{ }^{3-}$

$317<\mathrm{C}_{\mathrm{eq}}$; taken as $10 \mu \mathrm{M}$ (Van Cappellen and Berner, 1988). This assumes that the $\mathrm{PO}_{4}{ }^{3-}$ concentration is 318 the limiting factor for $\mathrm{CFA}$ precipitation rather than $\mathrm{Ca}^{2+}$ or $\mathrm{F}^{-}$, which is reasonable since apatite is 
more enriched in $\mathrm{P}$ than $\mathrm{F}$, and seawater $\mathrm{Ca}^{2+}$ concentrations are orders-of-magnitude higher (Froelich et al., 1983; Schuffert et al., 1994). A limiting term for $\mathrm{F}^{-}$is nonetheless included in the rate expression to ensure that CFA cannot crystallize if $\mathrm{F}^{-}$is completely consumed (Table S5). The rate constant for CFA precipitation is assigned to be $1 \mathrm{yr}^{-1}$ based on studies in Arabian Sea sediments (Kraal et al., 2012). A more rigorous expression for CFA precipitation that considers the effect of porewater $\mathrm{pH}$ and carbonate content should be explored in future work (Jahnke et al., 1983).

The depositional flux of apatite to the seafloor is set to zero (Table 2). We have chosen to omit detrital apatite from the model since it is believed to be unreactive (Berner et al., 1993). Vivianite precipitation is also not considered since this mineral is likely to be undersaturated in margin sediments (see Supplement). Estimates of the contribution by biogenic P (typically in the form of CFA fish bones and scales) to porewater dissolved $\mathrm{P}$ in sediments are scarce. Stoichiometric porewater models suggest that biogenic $\mathrm{P}$ contributes insignificantly to $\mathrm{PO}_{4}{ }^{3-}$ turnover in sediments outside of upwelling areas (Suess, 1981). Froelich et al. (1982) also calculated that burial of biogenic fish debris is a minor sink for $\mathrm{P}$ at the global scale. The fact that global fish production (ca. $2.5 \mathrm{~g} \mathrm{~m}^{-2}$ $\mathrm{yr}^{-1}$, Jennings et al., 2008) is equivalent to less than $2 \%$ of primary production (ca. $150 \mathrm{~g} \mathrm{~m}^{-2} \mathrm{yr}^{-1}$, Sarmiento and Gruber, 2006) seems to support this idea. For these reasons, biogenic P is considered to be inconsequential and is not included in the model (Froelich et al., 1982). Nonetheless, more work is needed to properly determine the importance of biogenically-derived $\mathrm{P}$ to benthic $\mathrm{P}$ fluxes.

\section{Parameterization of the phosphorus model}

\section{1. $C_{\text {org }}$ and $P_{\text {org }}$ mineralization}

A mechanistic understanding of $\mathrm{P}$ burial in sediments first requires a careful analysis of the poorly understood kinetics of $\mathrm{P}_{\text {org }}$ mineralization. Since $\mathrm{P}_{\text {org }}$ burial is often discussed in terms of $\mathrm{C}_{\text {org }}: \mathrm{P}_{\text {org }}$ ratios, the first step in the modelling procedure was to constrain the mineralization of $\mathrm{C}_{\text {org }}$ using the available database of organic carbon burial efficiencies (CBE) (Table 1).

The CBE in sediments on the continental margin under oxic bottom waters is $25 \pm 15 \%$ (Table 1) versus $>40 \%$ for oxygen-deficient bottom waters $\left(\mathrm{O}_{2}<20 \mu \mathrm{M}\right)$. This difference has been argued to be driven by preferential preservation of $\mathrm{C}_{\text {org }}$ in the absence of oxygen (Demaison and Moore, 1980;

347 Hartnett et al., 1998; Hedges et al., 1999). Running the anoxic model with $\mathrm{C}_{\text {org }}$ mineralization defined using the degradation kinetics for fresh phytoplankton (see 2. Methods) predicts a low CBE of $15 \%$. These kinetics thus over-predict $\mathrm{C}_{\text {org }}$ mineralization in natural anoxic sediments, probably because the experiments made no allowance for anaerobic mineralization (Westrich and Berner, 1984). The model 
distribution, $v$, from 0.125 to 0.05 , implying a greater fraction of less degradable components within the bulk organic mixture. Re-running the model gives a CBE of $47 \%$ for both anoxic and oxic sediments. Whilst this agrees with observations in anoxic sediments (Table 1), the predicted CBE in oxic (bioturbated and bioirrigated) sediments is too high. Enhanced $\mathrm{C}_{\text {org }}$ degradation under oxic bottom waters was thus achieved by multiplying the rate of aerobic $\mathrm{C}_{\text {org }}$ degradation by an acceleration factor, fox $C$ (see Table S5). With $f \circ x C=2$, for example, the model predicts a more realistic CBE of $16 \%$ for oxic sediments. This adjustment fits with the long-standing paradigm of preferential mineralization under oxic conditions (Hartnett et al., 1998; Hedges et al., 1999).

PBE is lowest in sediments underlying oxygen deficient bottom waters, with values in the range of 2 to $11 \%$ (Table 1). To achieve this with the model, it was necessary to enhance the dissolution of $\mathrm{P}_{\text {org }}$ during anaerobic respiration relative to $\mathrm{C}_{\text {org }}$ using an acceleration factor, fanoxP (Table S5). A value of 1.7 provides a PBE of $12 \%$ for the anoxic scenario that is in good agreement with previous studies with bottom water $\mathrm{O}_{2}<20 \mu \mathrm{M}$. The corresponding regeneration ratio, $(\mathrm{C}: \mathrm{P})_{\mathrm{REG}}$, is 64 , that is, $\mathrm{P}-$ enriched relative to the Redfield ratio of the organic matter raining to the seafloor. This also agrees with measured $(\mathrm{C}: \mathrm{P})_{\mathrm{REG}}$ of around 10-60 for anoxic margins (Table 1). Furthermore, the $\mathrm{C}_{\text {org }}: \mathrm{P}_{\text {org }}$ burial ratio is 423 , again well within the range of the observations (300 - 600).

If an equivalent acceleration factor of 1.7 is used for $\mathrm{P}_{\text {org }}$ mineralization relative to $\mathrm{C}_{\text {org }}$ during aerobic respiration $\left(\right.$ fox $P$ ), then $\mathrm{P}_{\text {org }}$ degradation is too high and the sediment loses too much $\mathrm{PO}_{4}{ }^{3-}$ by diffusion to the water column. The result is a PBE of only 5\% and a $\mathrm{C}_{\text {org }}: \mathrm{P}_{\text {org }}$ burial ratio of $335 . \mathrm{PBE}$ estimates for sediments under oxic bottom waters are scarce, and probably in the region of ca. 20 to $40 \%$, whilst burial ratios range from 30 to 115 (Table 1). Therefore, foxP must be less than fanoxP for the current model set-up. With foxP $=0.5$, that is, slower than the rate of aerobic $\mathrm{C}_{\text {org }}$ mineralization, the model predicts a PBE of $33 \%$ and a $\mathrm{C}_{\text {org }}: \mathrm{P}_{\text {org }}$ burial ratio of 53 for oxic sediments, respectively, both of which are supported by measured data. Furthermore, $(\mathrm{C}: \mathrm{P})_{\mathrm{REG}}$ is 140 , not dissimilar to observations under oxic bottom waters of $118 \pm 24$ (Wallmann, 2010).

\subsection{Preferential mineralization of $P_{\text {org }}$ versus $C_{\text {org }}$}

To summarize, the model can reproduce PBEs, $(\mathrm{C}: \mathrm{P})_{\mathrm{REG}}$ and $\mathrm{C}_{\text {org }}: \mathrm{P}_{\text {org }}$ burial ratios that are within the ranges of the field data if $\mathrm{P}_{\text {org }}$ mineralization proceeds at roughly half the rate of $\mathrm{C}_{\text {org }}$ mineralization during aerobic respiration and twice as fast during anaerobic respiration. In that case, we should expect to see $\mathrm{C}_{\text {org }}: \mathrm{P}_{\text {org }}$ ratios in oxic environments that are $\mathrm{P}$ enriched relative to Redfield $(<<106: 1)$.

383 However, field data rather indicate that $\mathrm{P}_{\text {org }}$ is mineralized preferentially to $\mathrm{C}_{\text {org }}$ under oxic conditions.

384 For instance, the molecular composition of particulate $\mathrm{P}$ sinking through oxic water columns down to ca. $4000 \mathrm{~m}$ in diverse oceanic settings has been analyzed using ${ }^{31} \mathrm{P}$ NMR (nuclear magnetic 
resonance) spectroscopy and sequential extractions (Paytan et al., 2003; Faul et al., 2005). These studies showed that phosphate diesters are preferentially solubilized, with $\mathrm{C}_{\text {org }}: \mathrm{P}_{\text {org }}$ ratios ranging from 276 to 1138 and a mean value of 318 . Selective $\mathrm{P}$ remineralization also occurs in the dissolved organic fraction. Clark et al. (1998) measured an increase in the C:P ratio of dissolved organic matter with depth in the Pacific Ocean from 247:1 at the surface to 539:1 at $4000 \mathrm{~m}$. Further examples of preferential mineralization of $P_{\text {org }}$ in oxic waters have been discussed by Ruttenberg (2014). The current model formulation of aerobic mineralization is thus inconsistent with the observations in the water column.

Although temporal and spatial variability of water column particle fluxes creates uncertainty in the data analysis (e.g. Paytan et al., 2003), it seems reasonable to assume that preferential mineralization of $\mathrm{P}_{\text {org }}$ relative to $\mathrm{C}_{\text {org }}$ continues in oxidized surface sediments. Identification of preferential $\mathrm{P}_{\text {org }}$ mineralization in sediments is more problematic because the thickness of the diffusive oxic layer at the sediment-water interface is typically only a few mm thick (Glud et al., 2008). Furthermore, $P_{\text {org }}$ dynamics are overprinted by inorganic $\mathrm{P}$ cycling and sediment reworking and mixing by bioturbation. Diagenetic models can help to eliminate such interferences. Using such an approach, Krom and Berner (1981) inferred preferential loss of $\mathrm{P}_{\text {org }}$ in surface sediments in Long-Island Sound by comparing the calculated $\mathrm{C}_{\text {org }}: \mathrm{P}_{\text {org }}$ stoichiometry of mineralized organic matter versus the bulk $\mathrm{C}_{\text {org }}: \mathrm{P}_{\text {org }}$ composition of the phytoplankton community. They further showed that $\mathrm{P}_{\text {org }}$ mineralization in the oxic layer was more rapid than in the underlying anoxic sediments. The empirical model developed by Ingall and Van Cappellen (1990) also required preferential regeneration of $\mathrm{P}_{\text {org }}$ to simulate $\mathrm{C}_{\text {org }}: \mathrm{P}_{\text {org }}$ burial ratios in a wide range of marine environments. In contrast, Reed et al. (2011) reported opposite trends for P turnover in a modern (seasonally) hypoxic basin. They tuned their model to data assuming selective $\mathrm{P}_{\text {org }}$ mineralization relative to $\mathrm{C}_{\text {org }}$ under anoxic conditions only.

Despite the ambiguity that exists concerning the extent of preferential mineralization of $\mathrm{P}_{\text {org }}$ relative to $\mathrm{C}_{\text {org }}$ under oxic conditions (Ruttenberg, 2014), the consensus seems to be that $\mathrm{P}_{\text {org }}$ is mineralized more rapidly than $\mathrm{C}_{\text {org }}$ during the initial stages of mineralization, and certainly not more slowly. Consequently, if $\mathrm{P}_{\text {org }}$ is indeed preferentially degraded in oxic sediments, then the $\mathrm{PO}_{4}{ }^{3-}$ that is released close to the sediment water interface must be sequestered and entrained in the sediment before it can escape to the water column. Constraints provided by $\mathrm{C}_{\text {org }}: \mathrm{P}_{\text {org }}$ burial ratios and PBE strongly indicate that this sink is organic in nature.

\subsection{Expanding the model: P sequestration by microorganisms}

The model is extended to include a simple microbial P cycle (Fig. 1) to investigate whether the hypothesized authigenic synthesis of refractive biomolecules (see Introduction) can explain 
preferential mineralization of $\mathrm{P}_{\text {org }}$ relative to $\mathrm{C}_{\text {org }}$ and the observed $\mathrm{C}: \mathrm{P}$ burial ratios in different marine settings. Two additional species are considered; polyphosphate $\left(\mathrm{P}_{\text {poly }}\right)$ and unreactive microbial organic $\mathrm{P}\left(\mathrm{P}_{\text {org- } \mathrm{U}}\right)$. The microorganisms are not modeled explicitly, and $\mathrm{P}_{\text {poly }}$ and $\mathrm{P}_{\text {org- } \mathrm{U}}$ are assumed to be particulate species transported passively through the sediments by bioturbation and burial. A deposition flux of zero is prescribed at the sediment surface for $\mathrm{P}_{\text {poly }}$ and $\mathrm{P}_{\text {org-U }}$ (Robin boundary), with a zero gradient at the bottom (Neumann boundary).

Microorganisms assimilate porewater $\mathrm{PO}_{4}{ }^{3-}$ in aerobic and nitrogenous sediments leading to an increase in the $\mathrm{P}_{\text {poly }}$ pool (Davelaar, 1993). A fraction $\left(f_{\text {poly }}\right)$ of $\mathrm{P}_{\text {poly }}$ is converted to $\mathrm{P}_{\text {org-u }}$ to simulate the synthesis of refractive $\mathrm{P}$ biomolecules. This fraction is buried without further reaction and constitutes a microbial $\mathrm{P}$ pump that removes bioavailable $\mathrm{P}$ from the ocean. The remainder $\left(1-f_{\text {poly }}\right)$ is recycled back to the bulk $\mathrm{P}_{\text {org }}$ pool on the understanding that labile dead bacterial biomass is remineralized. $\mathrm{P}_{\text {poly }}$ that is transported into anaerobic sediment layers is rapidly hydrolyzed back to $\mathrm{PO}_{4}{ }^{3-}$. This simulates the breakdown of $\mathrm{P}_{\text {poly }}$ by bacteria to gain energy to survive anaerobiosis as well as the lack of $\mathrm{P}_{\text {poly }}$ in anoxic sediments (Gächter and Meyer, 1993; Davelaar, 1993; Sannigrahi and Ingall, 2005; Schulz and Schulz, 2005; Brock and Schulz-Vogt, 2010). Phosphate that is released to the porewater can be trapped in authigenic phases (sink switching) or diffuse upwards and reassimilated by bacteria as $\mathrm{P}_{\text {poly }}$. Transformation of $\mathrm{P}_{\text {poly }}$ into CFA is not considered (Diaz et al., 2008), although we recognize that this may take place in oxygen minimum zones (Goldhammer et al., 2010).

The proposed cycle is by necessity highly simplified since the distribution of different classes of organically-bound P molecules in sediments is not well understood and polyphosphates are typically extracted in operationally defined $\mathrm{P}_{\text {org }}$ pools (Sannigrahi and Ingall, 2005; Diaz et al., 2012). X-ray spectromicroscopy has nonetheless revealed that polyphosphates are an important $\mathrm{P}$ phase at oxicanoxic interfaces in marine sediments, and that they may constitute a larger fraction of the operationally-defined detrital P than previously assumed (Diaz et al., 2008; Kraal et al., 2015). With this in mind, the following equation describing the rate of change of $\mathrm{P}_{\text {poly }}$ in the sediment is proposed:

$\frac{\mathrm{d} \mathrm{P}_{\text {poly }}}{\mathrm{d} t}=+$ synthesis - hydrolysis $-\mathrm{P}_{\text {org-U }}$ synthesis $-\mathrm{P}_{\text {org }}$ synthesis

446 The kinetics and parameterization of these pathways are only vaguely constrainable by field and 447 experimental observations. We make the assumption that the rate of $\mathrm{P}_{\text {poly }}$ synthesis $\left(\mathrm{R}_{30}\right)$ is dependent 448 on the concentration of $\mathrm{PO}_{4}{ }^{3-}$ in the porewater as well as the concentration of $\mathrm{NO}_{\mathrm{X}}\left(\mathrm{NO}_{3}{ }^{-}+\mathrm{NO}_{2}{ }^{-}\right)$:

$449 \mathrm{R}_{30}=k_{30} \cdot \mathrm{PO}_{4}{ }^{3-} \cdot \mathrm{NO}_{\mathrm{X}}$

where $k_{30}$ is the rate constant. No dependency on $\mathrm{O}_{2}$ is included because it is exhausted before $\mathrm{NO}_{\mathrm{X}}$, such that the sediment penetration depth of $\mathrm{NO}_{\mathrm{X}}$ is higher than for $\mathrm{O}_{2}$ (discussed below). The impact of $\mathrm{C}$ limitation on $\mathrm{P}_{\text {poly }}$ synthesis is not considered (Steenbergh et al., 2012). 
Hydrolysis of $\mathrm{P}_{\text {poly }}$ is defined using a dimensionless oxygen threshold, $\delta$ :

where $\delta=0$ for $\mathrm{O}_{2} \geq 1 \mu \mathrm{M}$ and $\delta=1$ for $\mathrm{O}_{2}<1 \mu \mathrm{M}$. Transformation of $\mathrm{P}_{\text {poly }}$ to $\mathrm{P}_{\text {org }}\left(\mathrm{R}_{32}\right)$ and $\mathrm{P}_{\text {org-U }}$ $\left(\mathrm{R}_{33}\right)$ are described as first-order processes:

$\mathrm{R}_{32}=k_{32} \cdot\left(1-f_{\text {poly }}\right) \cdot \mathrm{P}_{\text {poly }}$

459 The rate coefficients $k_{31}$ to $k_{33}$ are set to high values of $50 \mathrm{yr}^{-1}$. Rapid turnover of $\mathrm{P}_{\text {poly }}$ has been 460 inferred from the transient development of large subsurface $\mathrm{PO}_{4}^{3-}$ peaks attributed to the breakdown 461 of bacterial $P_{\text {poly }}$ (Schulz and Schulz, 2005; Dale et al., 2013). The rate limiting step in the microbial P 462 cycle is $\mathrm{P}_{\text {poly }}$ synthesis, such that the turnover of microbial $\mathrm{P}$ pump can be regulated by adjusting $k_{30}$ 463 whereas the fraction channeled into refractive $\mathrm{P}_{\text {org-U }}$ is determined by $f_{\text {poly }}$. Fast transformation of $\mathrm{PO}_{4}{ }^{3-}$ 464 into $\mathrm{P}_{\text {poly }}$ by sulfur oxidizing bacteria has been measured using ${ }^{33} \mathrm{P}$ tracer (Goldhammer et al., 2010). 465 We acknowledge the possibility, and likelihood, that a different set of parameters or microbial $\mathrm{P}$ 466 cycling pathways could lead to equivalent results. Our main interest here is whether $\mathrm{P}_{\text {org }}$ synthesis by 467 bacteria is a concept that is supported by the data.

468 On the understanding that aerobic $\mathrm{P}_{\text {org }}$ mineralization is more rapid than $\mathrm{C}_{\text {org }}$ mineralization, we initially set foxP , the enhancement of aerobic $\mathrm{P}_{\text {org }}$ mineralization relative to $\mathrm{C}_{\text {org }}$, equal to 2 . We then adjusted the rate of $\mathrm{P}_{\text {poly }}$ synthesis to bring the model back into the range of the observations.

\section{Results}

The model with the microbial P pump is able to simulate the entire suite of field observations in oxic and anoxic sediments with $k_{30}=3 \times 10^{7} \mathrm{M}^{-1} \mathrm{yr}^{-1}$ and a slightly higher fanoxP of 2 (Table 2 and 3). The latter adjustment from the previous value of 1.7 compensates for the limited amount of microbial $\mathrm{P}_{\text {org }}$ that is synthesized in the nitrogenous layer in the anoxic sediment. Furthermore, $f_{\text {poly }}$ is equal to 0.25 , such that $25 \%$ of the $\mathrm{P}_{\text {poly }}$ pool that is not hydrolyzed is converted to $\mathrm{P}_{\text {org-U }}$ and $75 \%$ to $\mathrm{P}_{\text {org. }}$. The relative fractionation of $\mathrm{P}_{\text {poly }}$ into labile and unreactive $\mathrm{P}_{\text {org }}$ depends somewhat on the poorly constrained values of foxP. Whilst there is obviously some latitude in these numbers, we note that the model would not be able to simulate the database if $\mathrm{P}_{\text {poly }}$ were entirely converted to $\mathrm{P}_{\text {org }}$ or $\mathrm{P}_{\text {org-u }}$ alone. An important conclusion from this model set-up is that $\mathrm{P}_{\text {org }}$ is preferentially mineralized relative to $\mathrm{C}_{\text {org }}$ during aerobic and anaerobic respiration. 
The mass fluxes in Fig. 2 show that $\mathrm{P}$ turnover is more intense in oxic sediments. $\mathrm{P}_{\text {org }}$ mineralization rates are $136 \mu \mathrm{mol} \mathrm{m} \mathrm{m}^{-1}$, versus $89 \mu \mathrm{mol} \mathrm{m} \mathrm{m}^{-2}$ in anoxic sediments. This is partly compensated by

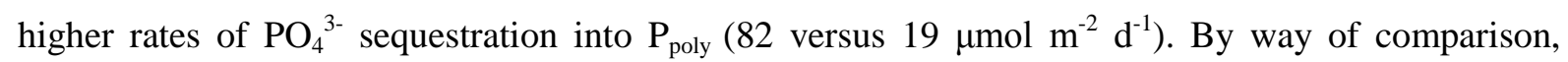
measured $\mathrm{P}$ sequestration rates by sulfur oxidizing bacteria are of a similar magnitude (210 to 780 $\mu \mathrm{mol} \mathrm{m} \mathrm{m}^{-1}$; Goldhammer et al., 2010). As a result, $\mathrm{PO}_{4}{ }^{3-}$ concentrations are lower in oxic sediments and $\mathrm{P}_{\text {org }}$ and $\mathrm{P}_{\text {reac }}$ concentrations are higher (green and black curves, Fig. 3). Identical qualitative trends have been observed at neighboring oxic and anoxic sites in Effingham Inlet (Ingall et al., 2005; Sannigrahi and Ingall, 2005). Removing the microbial $\mathrm{P}$ pump leads to complete dissolution of $\mathrm{P}_{\mathrm{org}}$ in oxic sediments and low accumulation of other authigenic $\mathrm{P}$ phases (red curves, Fig. 3).

\section{Discussion}

\subsection{P cycling with the microbial P pump}

The simulated $\mathrm{P}$ dynamics considering microbial $\mathrm{P}$ sequestration and burial are consistent with the observed burial efficiencies, benthic fluxes and burial ratios in diverse marine settings, and suggest an important microbial control of $\mathrm{P}$ cycling in sediments. Permanent microbial $\mathrm{P}$ sequestration can be viewed as a sink-switching mechanism that permits preferential burial of $\mathrm{P}$ relative to $\mathrm{C}_{\text {org }}$ (Ruttenberg and Berner, 1993; Filippelli and Delaney, 1996; Anderson et al., 2001). Microorganisms may, therefore, act as a barrier to $\mathrm{PO}_{4}{ }^{3-}$ fluxes in the same way as $\mathrm{P}$ sequestration by iron oxides and apatite crystallization (Sundby et al., 1992; Gächter and Meyer, 1993; Anschutz et al., 1998; Slomp et al., 1996; Sannigrahi and Ingall, 2005). Microbial sink-switching leads to $\mathrm{C}_{\text {org }}: \mathrm{P}_{\text {reac }}$ burial ratios of 44 and 196 in oxic and anoxic sediments, respectively (Table 3). These agree well with those measured above and within Mediterranean sapropels (21 versus 54 - 161; Slomp et al., 2004) and with values of $140 \pm 50$ and $180 \pm 90$ from (anoxic) black shale sequences from the Cayuga Basin and Yorkshire coast (Ingall et al., 1993; Anderson et al., 2001).

In the current oxic configuration, $\mathrm{PO}_{4}{ }^{3-}$ trapping into iron oxides (ca. $9 \mu \mathrm{mol} \mathrm{m}{ }^{-2} \mathrm{~d}^{-1}$; Fig. 2) removes a relatively small fraction of $\mathrm{PO}_{4}{ }^{3-}$ from the porewater compared to microbial P. This result arises from tuning the model to the observational database in Table 1, and involves no tweaking of other parameters to lessen the importance of Fe-P cycling. The iron cycle has been previously constrained from a global empirical database (Dale et al., 2015a). A lesser contribution (quantitatively speaking) of iron-associated $\mathrm{P}$ cycling on $\mathrm{P}$ burial relative to $\mathrm{P}_{\text {org }}$ is consistent with previous findings from some settings (Ruttenberg and Berner, 1997; Ingall and Jahnke, 1997; Sannigrahi and Ingall, 2005) but not others (Jensen et al., 1995; Slomp et al., 1996). This can be attributed potentially to numerous factors, such as regional variability in external iron inputs, bottom water $\mathrm{O}_{2}$ levels, and bioirrigation and bioturbation intensities. Model sensitivity analysis (not shown) reveals that the fraction of $\mathrm{P}$ that is 
buried in association with iron oxides is particularly sensitive to the Fe:P molar ratio in the iron fraction of $\mathrm{Fe}_{\mathrm{MR}}$ that is crystallized from $\mathrm{Fe}_{\mathrm{HR}}$ by ageing $\left(\varepsilon_{a g e}\right)$. This ratio is set to 40, compared to a molar ratio of 10 for freshly precipitated $\mathrm{Fe}_{\mathrm{HR}}$. The higher value represents an increase in the crystallinity of $\mathrm{Fe}_{\mathrm{MR}}$ relative to $\mathrm{Fe}_{\mathrm{HR}}$ and subsequent loss of $\mathrm{P}$ binding sites (see 2. Model). The rate of $\mathrm{PO}_{4}{ }^{3-}$ that is sequestered into $\mathrm{Fe}_{\mathrm{MR}}$ by ageing is proportional to $\varepsilon_{a g e}$, such that a halving of $\varepsilon_{\text {age }}$ doubles the burial flux of $\mathrm{P}$ associated with $\mathrm{Fe}_{\mathrm{MR}}$. Thus, precipitation and ageing of $\mathrm{FeP}$ could conceivably sequester more $\mathrm{PO}_{4}{ }^{3-}$ than currently assumed by the model. It cannot, however, explain the entire sink for $\mathrm{PO}_{4}{ }^{3-}$ because this would be inconsistent with the $\mathrm{C}_{\text {org }}: \mathrm{P}_{\text {org }}$ burial ratios and $\mathrm{P}_{\text {org }}$ burial efficiencies.

The fact that total $\mathrm{P}_{\text {org }}$ in oxic settings is roughly twice that in anoxic sediments demonstrates that recalcitrant microbial $\mathrm{P}_{\text {org }}$ constitutes around half of the $\mathrm{P}_{\text {org }}$ buried below the bioturbated layer (Fig. 3). A higher turnover of microbial biomass under oxic versus anoxic conditions has been noted before (Sun et al., 2002), and conceivably could be coupled to a more intense microbial P pump. In this study, we did not explicitly examine the $\mathrm{C}_{\text {org }}: \mathrm{P}_{\text {org }}$ ratio of the microorganisms or simulate microbial $\mathrm{C}_{\text {org }}$. The $\mathrm{C}_{\text {org }}: \mathrm{P}_{\text {org }}$ ratio of bacteria has been often cited to be between 29 and 63 (Berner et a., 1993), which is close to the simulated ratio in oxic sediments of 73 (Table 3). Yet, X-ray microanalysis on intact cells from surface sediment samples in the Baltic Sea revealed high bacterial $\mathrm{C}_{\text {org }}: \mathrm{P}_{\text {org }}$ ratios up to 400 , although this may be related to substrate $\left(\mathrm{C}_{\text {org }}\right)$ limitation (Steenbergh et al., 2012). This type of quantitative information could serve to further validate the model if the degradation kinetics of cellular $\mathrm{P}_{\text {org }}$ were known, for both oxic and anoxic sediments. Compared to FeP and CFA, microbial P cycling in marine sediments has hardly been studied, resulting in a severe lack of information on the genesis and reactivity of sedimentary $\mathrm{P}_{\mathrm{org}}$. Consequently, the significance of the benthic microbial $\mathrm{P}$ pump to the global $\mathrm{P}$ cycle can only be inferred currently using observations of the bulk $\mathrm{P}$ pool.

\subsection{The impact of animals on P burial}

541 Our results show that sediments on the modern marine shelf that are mixed and ventilated by bioturbation and bioirrigation are around $50 \%$ more efficient at retaining $\mathrm{P}$ than sediments under anoxic bottom waters, with net $P_{\text {reac }}$ accumulation rates of 35 and $23 \mu \mathrm{mol} \mathrm{m} \mathrm{m}^{-2} \mathrm{~d}^{-1}$, respectively (Fig. 2). The $P_{\text {reac }}$ burial flux scales positively with $\mathrm{O}_{2}$ availability (solid black curve, Fig. 4a; the grey shaded area shows the range of $\mathrm{P}$ burial expected for all values of $f_{p o l y}$ ), and the effect of $\mathrm{O}_{2}$ is stronger for sediments that are more intensively reworked by bioturbation and bioirrigation (dashed black curves). The direct contribution of bioturbation and bioirrigation is shown by observing the lower $\mathrm{P}_{\text {reac }}$ accumulation rates in simulations without benthic infauna (dashed blue curves in Fig. 3 and Fig. 4a). It is interesting to note that here the burial flux initially decreases for $\mathrm{O}_{2}<20 \mu \mathrm{M}$ due to a weak microbial $\mathrm{P}$ pump and preferential dissolution of $\mathrm{P}_{\text {org }}$ by aerobic respiration (Fig. 4a). A reversal in $\mathrm{P}_{\text {reac }}$ burial when $\mathrm{O}_{2}>20 \mu \mathrm{M}$ marks the point where synthesis and burial of $\mathrm{P}_{\text {org-U }}$ begins to mitigate 
the $\mathrm{PO}_{4}^{3-}$ flux to the bottom water. $\mathrm{P}_{\text {reac }}$ burial in model runs with mixing but without microbial $\mathrm{P}$ uptake are even lower (dashed red curves in Fig. 3 and Fig. 4).

These results demonstrate that enhanced $\mathrm{P}$ burial may not only be driven by $\mathrm{O}_{2}$ availability, as assumed in some modeling studies (Van Cappellen and Ingall, 1994; Slomp and Van Cappellen, 1994), but requires the intervention of P-storing microorganisms and animals to churn and ventilate the sediment. Enhanced $\mathrm{P}$ burial in oxic sediments with faunal communities is explained mechanistically as follows. First, bioturbation limits diffusive $\mathrm{PO}_{4}{ }^{3-}$ fluxes to the bottom water by shunting highly labile $\mathrm{P}_{\text {org }}$ away from the aerobic sediment layers where mineralization rates are elevated. This can be appreciated by noting that $\mathrm{P}_{\text {org }}$ mineralization rates in the top millimeter of bioturbated sediments are several-fold lower than for non-bioturbated sediments, whereas the opposite is true below this depth (Fig. 5). Sub-surface mineralization of $\mathrm{P}_{\text {org }}$ helps to trap $\mathrm{P}$ within the sediment by sink-switching. Without bioturbation, $\mathrm{P}_{\text {org }}$ can only be transported downwards by the relatively slow process of burial, allowing more $\mathrm{P}_{\text {org }}$ to be solubilized to $\mathrm{PO}_{4}{ }^{3-}$ at the sediment-water interface and released back to the ocean. Slomp et al. (1996) similarly proposed that P trapping in North Atlantic slope sediments is favored by the downward mixing of iron-bound $\mathrm{P}$ by infauna followed by sink-switching to CFA. Our result is partly dependent on the reverse conveyor belt feeding mechanism of bioturbation (see 2. Model). It is likely, however, that other bioturbation formalisms result in a similar redistribution of labile $\mathrm{P}_{\text {org }}$, although we have not tested these explicitly.

Second, seawater pumping into the sediment by bioirrigation enhances nitrification and creates a more favorable niche for P-storing bacteria by deepening the nitrogenous sediment zone relative to oxidized, non-mixed sediments (compare green and dashed blue curve, Fig. 3b). This result is partly dependent on the kinetics of nitrate $\left(\mathrm{NO}_{\mathrm{X}}\right)$ consumption and the irrigation coefficient, $\alpha(0)$, that are somewhat poorly constrained at the global scale. Deeply-burrowing polychaetes can result in large nitrate penetration depths (Dale et al., 2011; Renz and Forster, 2014), although not all irrigated sediments show the same features (Devol and Christensen, 1993; Dale et al., 2014). In reality, patterns of solute transport in and around burrows are much more complex than portrayed with the simple irrigation model used here. The thickness of the oxic and nitrogenous zones will depend on many physical and biological factors such as the sediment permeability, bottom water currents and the ecology of each animal species. Nonetheless, the deeper nitrogenous zone with versus without animals supports the proposed rate formulation for $\mathrm{P}_{\text {poly }}$ synthesis (Eq. (12)). Again, it is important to stress that Eq. (12) is purely conceptual, although it does conform to the known redox window over which microbial P sequestration occurs (Davelaar, 1993). It should also be noted that $\mathrm{O}_{2}$ concentrations with animals are also on average $50 \%$ higher than in the case without them (Fig. $3 \mathrm{a}$ ). Inclusion of $\mathrm{O}_{2}$ into Eq. (12), for example by making $\mathrm{P}_{\text {poly }}$ synthesis dependent on the sum of $\mathrm{NO}_{\mathrm{X}}+$ $\mathrm{O}_{2}$, would require recalibration of the rate constant, $k_{30}$, but would not fundamentally alter the main results. 


\subsection{Implications for P burial in the early Paleozoic}

590 We modified the model to assess the dynamics of $\mathrm{P}$ burial in the early Paleozoic to test the hypothesis advanced by Boyle et al. (2014) that colonization of the continental shelves by bioturbating and burrowing animals at some time between the Ediacaran and early Paleozoic resulted in enhanced $\mathrm{P}$ burial. A more nuanced view is now emerging in the palaeontological literature, in which the full scale of the "Cambrian substrate revolution" may have been delayed, perhaps until as late as the Ordovician-Silurian boundary or late Silurian (Tarhan et al., 2015). In other words, there may have been a delay between the appearance of the first trace fossils and quantitatively significant mixing of continental shelf sediments (Tarhan and Droser, 2014).

Although the timing and trajectory of the spread of faunal invasion of sediments is still being worked out, it seems certain that at some point between ca. 550 Ma and 420 Ma the bioturbation intensity and burrow depth increased. There is high uncertainty in assigning real numbers to these parameters, and the consensus on this issue is evolving. Mángano and Buatois (2014) reported an increase in maximum burrow depth from around 1 to $6 \mathrm{~cm}$ across the Ediacaran/ Paleozoic boundary based on trace fossil specimen analysis. In contrast, sedimentological data suggest that burrow depths in the lower Cambrian never exceeded $3 \mathrm{~cm}$, and bed thicknesses point toward millimetre-scale mixing depths in the lower to middle Cambrian (ca. $542-507 \mathrm{Ma}$ ) increasing to $1-2 \mathrm{~cm}$ in the Ordovician Silurian (ca. 450 - $420 \mathrm{Ma}$ ) (Tarhan and Droser, 2014). Clearly, sediment mixing and burrowing depths during the early Cambrian were significantly lower than they are on ocean margins today.

In accordance with these latest data, the mixed depth was reduced to $0.5 \mathrm{~cm}\left(z_{b t}=0.25 \mathrm{~cm}\right)$. Bioirrigation was also reduced so that the burrow flushing intensity at $2 \mathrm{~cm}$ depth was $\sim 10 \%$ of the surface value $\left(z_{b i o}=1 \mathrm{~cm}\right)$. P burial is insensitive to lower $z_{b i o}$ values since solute transport in the uppermost sediment layer is dominated by diffusive exchange with the bottom water. To account for the lower bioturbation intensity in sediments this time, the sediment mixing intensity $\left(D_{b}(0)\right)$ was decreased arbitrarily from 27 to $5 \mathrm{~cm}^{2} \mathrm{yr}^{-1}$ and bioirrigation $(\alpha(0))$ from $465 \mathrm{y}^{-1}$ to $50 \mathrm{y}^{-1}$. Due to the near-impossibility of constraining these latter values accurately, the model focuses on a qualitative comparison between sediments with and without indwelling fauna in the early Paleozoic.

The paleo simulations also account for the different boundary conditions at the sediment-water interface. Geochemical evidence that is interconnected with ancient ocean redox status allows some essential features to be reasonably well described (Och and Shields-Zhou, 2012). The deep ocean in the early Paleozoic was ferruginous, with euxinic conditions restricted to the biologically productive margins (Canfield et al., 2008; Li et al., 2010; Lyons et al., 2014). The shallow seas, in contrast, may 
621 have been similar to productive regions in the contemporary ocean and experienced oxic bottom 622 waters (Kendall et al., 2012; Lyons et al., 2014).

623 Constraints on global oxygen levels are qualitative at best for this period of Earth's history. Late 624 Ediacaran / early Paleozoic $\mathrm{O}_{2}$ concentrations and may have been several tens of $\mu \mathrm{M}$ (Canfield et al., 625 2007; Bjerrum and Canfield, 2011), with anoxic episodes persisting well into the early Paleozoic 626 (Saltzman et al., 2015). As a reflection of this uncertainty, we assessed P burial over the same range 627 of bottom water $\mathrm{O}_{2}$ concentrations as previously ( 0 to $\left.150 \mu \mathrm{M}\right)$.

628 Sulfate $\left(\mathrm{SO}_{4}{ }^{2-}\right)$ concentrations in the early Paleozoic ocean were also much lower than today. 629 Concentrations following the Great Oxygenation Event (2.4 Ga) may have remained at only $1-3 \mathrm{mM}$ 630 until the Cambrian or even later, when bioturbation itself may have contributed to a rise in $\mathrm{SO}_{4}{ }^{2-}$ via 631 increased oxidation of sedimentary sulfide (Canfield and Farquhar, 2009; Li et al., 2010; Tarhan et al., 632 2015). We used a sulfate concentration of $3 \mathrm{mM}$, and kept all other model parameters at their modern 633 values, including the sedimentation rate. This assumption relates to fact that continental weathering 634 rates at the end of the Ediacaran appear to have been similar to those of today (Maloof et al., 2010; 635 Peters and Gaines, 2012). Sensitivity analysis (not shown) indicates that $\mathrm{P}$ burial scales proportionally with sedimentation rate.

637 Knowledge of the flux and lability of organic matter deposited on the sea floor in the early Paleozoic 638 is completely lacking, and we prescribe the contemporary values in the absence of better information. 639 Given that photosynthetic eukaryotes evolved more than $1500 \mathrm{Ma}$, the biochemical composition and 640 cell size of photosynthesizing biota may have been comparable to today, even though species 641 diversity was lower (Falkowski et al., 2004; Butterfield, 2007; Och and Shields-Zhou, 2012). In that 642 case, particle fluxes would be still be eukaryote-dominated, enhanced by aggregation and ballasting 643 resembling the modern ocean (Lenton et al., 2014). Running the model using the same organic matter 644 flux and reactivity as for the modern scenario will elucidate the impact of ocean chemistry and 645 sediment mixing on $\mathrm{P}$ burial. These assumptions can be relaxed if more data becomes available.

646 Model results of the early Paleozoic scenario with bottom water $\mathrm{O}_{2}$ concentrations of $25 \mu \mathrm{M}$ show 647 that, in general, the redox structure is not dramatically different from the modern scenario (Fig. S1 648 and S2). Notably, though, the aerobic and nitrogenous layers are less well developed due to the lower 649 bottom water $\mathrm{O}_{2}$ concentrations, sediment mixing and irrigation rates. Over the range of $\mathrm{O}_{2}$ levels 650 tested, this causes a decrease in $\mathrm{P}$ burial relative to the modern setting mainly as result of lower 651 microbial $P_{\text {org }}$ accumulation (black curve in Fig. $4 \mathrm{~b}$ and Supplement). The results nonetheless show 652 that, even with a much thinner and weakly mixed surface layer, the onset of bioturbation at the low $\mathrm{O}_{2}$ 653 concentrations of some $10 \mathrm{~s} \mu \mathrm{M}$ believed to characterize this time period (Canfield et al., 2007; 654 Bjerrum and Canfield, 2011) would have increased P burial, shown schematically by the blue arrow in 
Fig. 4b. Further increases in the depth of the mixed layer in the late Cambrian lead to even greater burial of $\mathrm{P}$ (black arrow).

657 These results are of qualitative value only due to the assumptions involved in constraining the boundary conditions in ancient sediments. We also assumed for simplicity that the physical aspects of bioturbation, such as particle disaggregation and modification of the sediment fabric as well as feeding mode (local versus non-local), resemble modern sediments. We tested the effect of changes in sediment water content arising from colonization by indwelling fauna. Deckere et al. (2001) observed a lower water content of defaunated versus faunated sediment experiments, and other natural observations have shown that seasonal anoxia and lack of bioirrigation reduces sediment porosity by around $10 \%$ (Dale et al., 2013). Anoxic baseline simulations with a $10 \%$ lower porosity show a modest decrease in $\mathrm{P}_{\text {reac }}$ burial from 23 to $18 \mu \mathrm{mol} \mathrm{m} \mathrm{m}^{-2}$, driven by an increase in solid fraction mineralization close to the sediment water interface and subsequent loss of $\mathrm{PO}_{4}{ }^{3-}$. Early sediment colonization may thus have had a greater effect on $\mathrm{P}_{\text {reac }}$ burial than the baseline model currently predicts.

The oceanic P residence time (ca. $20 \mathrm{kyr}$, Wallmann, 2010) is relatively short compared to the $>10^{5}$ years needed for the stabilizing feedbacks on the oceanic $\mathrm{P}$ inventory via redox-dependent $\mathrm{P}$ burial (Van Cappellen and Ingall, 1994; Lenton and Watson., 2000). Thus, the radiation of indwelling sediment fauna would have helped to lower the oceanic bioavailable P pool over these long time scales, leading to a negative and stabilizing feedback on atmospheric $\mathrm{O}_{2}$ levels via primary production (Boyle et al., 2014). This could have contributed to a wider stability in the Earth system that may have been necessary for the proliferation of recently developed animal forms that characterize the early Cambrian (Butterfield, 2007; 2009). The results presented here show mechanistically how animals may have 'engineered' the physical, geochemical and microbiological structure of their habitats, leading to stabilizing negative feedbacks with the $\mathrm{O}_{2}$ levels upon which they depend, with wider implications for the coevolution of the earth system and animal forms (Mermillod-Blondin and Rosenberg, 2006; Butterfield, 2007; 2009; Boyle et al., 2014). In combination with microbial catalysis of bioavailable $\mathrm{P}$ into organic compounds, animals very likely exert an important control on the cycling of burial of $\mathrm{P}$ in the modern and ancient ocean.

\section{Conclusions}

Observed $\mathrm{C}$ and $\mathrm{P}$ burial and recycling rates from the literature interpreted with a diagenetic model strongly suggest that uptake and recycling of $\mathrm{P}$ by microorganisms enhances $\mathrm{P}$ burial in bioturbated and bioirrigated marine sediments alongside iron-associated phosphorus and authigenic apatite formation. Whilst microbial cycling of $\mathrm{P}$ has been recognized for many years by limnologists, and inferred from $\mathrm{C}_{\text {org }}: \mathrm{P}_{\text {org }}$ burial ratios and benthic fluxes by marine geochemists, redox-dependent storage and burial of refractory microbial $\mathrm{P}$ (termed the microbial $\mathrm{P}$ pump) has thus far not been 
included in diagenetic models of $\mathrm{P}$ cycling in marine sediments. Microbial $\mathrm{P}$ sequestration in 691 conjunction with bioturbation intensity and bottom water $\mathrm{O}_{2}$ levels (summarized in Fig. 4) should be 692 considered when parameterizing redox-dependent benthic P release in global biogeochemical models.

$693 \mathrm{O}_{2}$ concentration by itself may be insufficient to explain benthic phosphate fluxes in periods in Earth's 694 history when bioturbating and burrowing fauna colonized or recolonized the seafloor. Our results support the notion that the presence of $\mathrm{P}_{\text {org }}$ in ancient marine sediments could, in part, be due to the synthesis of refractive microbial compounds in surface sediments.

More accurate information regarding the controls on microbial sequestration of porewater $\mathrm{PO}_{4}{ }^{3-}$ by, for example, organic carbon content and reactivity, sedimentation rate and bottom water redox conditions and well as physiological controls on $\mathrm{P}$ uptake in natural sediments awaits further study. New approaches to quantify microbial P biomarkers or polyphosphates such as X-ray spectroscopy (XANES) will be invaluable to expand the database on the microbial P content of surface sediments in settings displaying a range of bottom water redox conditions (e.g. Kraal et al., 2015).

\section{Acknowledgements}

705

706

The authors thank Lidya Tarhan and an anonymous referee for comprehensive and thoughtful reviews and Tim Lyons for the editorial handling. This work is a contribution of the Sonderforschungsbereich 754 "Climate - Biogeochemistry Interactions in the Tropical Ocean" (www.sfb754.de) which is supported by the Deutsche Forschungsgemeinschaft.

\section{References}

Algeo, T. J. and Ingall, E. (2007) Sedimentary Corg:P ratios, paleocean ventilation, and Phanerozoic atmospheric pO2. Palaeogeogr. Palaeoclimatol. Palaeoecol. $256,130-155$.

Aller, R. C. and Aller, J. Y. (1992) Meiofauna and solute transport in marine muds. Limnol. Oceanogr. 37, 1018-1033.

Anderson, L. D., Delaney, M. L. and Faul, K. L. (2001) Carbon to phosphorus ratios in sediments: Implications for nutrient cycling. Glob. Biogeochem. Cy. 15, 64-79.

Anschutz, P., Zhong, S. and Sundby, B. (1998) Burial efficiency of phosphorus and the geochemistry of iron in continental margin sediments. Limnol. Oceanogr. 43, 53-64.

Archer, D. E., Morford, J. L. and Emerson, S. R. (2002) A model of suboxic sedimentary diagenesis suitable for automatic tuning and gridded global domains. Glob. Biogeochem. Cy. 16, 1017, doi:10.1029/2000GB001288.

Bale, A. J. Morris, A. W. (1981) Laboratory simulation of chemical processes induced by estuarine mixing: The behaviour of iron and phosphate in estuaries. Estuar. Coast. Shelf Sci.13, 1-10.

Benitez-Nelson, C. R. (2000) The biogeochemical cycling of phosphorus in marine systems. Earth-Sci. Rev. 51, 109-135.

Berner, R. A. (1980) Early Diagenesis: A Theoretical Approach. Princeton University Press, Princeton, 241 pp.

Berner, R. A. and Rao, J. L. (1994) Phosphorus in sediments of the Amazon River and estuary: Implications for the global flux of phosphorus to the sea. Geochim. Cosmochim. Acta 58, 2333-2339. 
Berner, R. A., Ruttenberg, K. C., Ingall, E. D. and Rao, J. L. (1993) The nature of phosphorus burial in modern marine sediments. In Interactions of C, N, P and S Biogeochemical Cycles and Global Change, NATO ASI Ser., Ser. I, vol. 4, (eds. R. Wollast, F. T. Mackenzie, and L. Chou), Springer, Berlin, pp. 365- 378.

Bertics, V. J., Sohm, J. A., Treude, T., Chow, C. E. T., Capone, D. G. Fuhrman, J. A., and Ziebis, W. (2010) Burrowing deeper into benthic nitrogen cycling: The impact of bioturbation on nitrogen fixation coupled to sulfate reduction, Mar. Ecol. Prog. Ser., 409, 1-15.

Bjerrum, C. J. and Canfield, D. E. (2011) Towards a quantitative understanding of the late Neoproterozoic carbon cycle. Proc. Natl. Acad. Sci. U.S.A. 108, 5542-5547.

Borggaard, O. K. (1991) Effects of phosphate on iron oxide dissolution in ethylenediamine-N,N,N'N'-tetraacetic acid and oxalate. Clays Clay Miner. 39, 324-328.

Boudreau, B. P. (1986) Mathematics of tracer mixing in sediments; I. Nonlocal mixing and biological conveyorbelt phenomena. Am. J. Sci. 286, 161-198.

Boudreau, B. P. (1997) Diagenetic Models and Their Implementation: Modelling Transport and Reactions in Aquatic Sediments, Springer-Verlag, Berlin, 414 pp.

Boudreau, B. P., Arnosti, C., Jorgensen, B. B. and Canfield, D. E. (2008) Comment on "Physical Model for the Decay and Preservation of Marine Organic Carbon". Science 319, 1616-1617.

Boudreau, B. P. and Ruddick, B. R. (1991) On a reactive continuum representation of organic matter diagenesis. Am. J. Sci. 291, 507-538.

Boyle, R. A., Dahl, T. W., Dale, A. W., Shields-Zhou, G. A., Zhu, M., Brasier, M. D., Canfield, D. E. and Lenton, T. M. (2014) Stabilization of the coupled oxygen and phosphorus cycles by the evolution of bioturbation. Nat. Geosci. 7, 671-676.

Brock, J. and Schulz-Vogt, H. N. (2010) Sulfide induces phosphate release from polyphosphate in cultures of a marine Beggiatoa strain. ISME J. 5, 497-506.

Burdige, D. J. (2006) Geochemistry of Marine Sediments, Princeton Univ. Press, Princeton, N. J.

Burdige, D. J. (2007) Preservation of organic matter in marine sediments: controls, mechanisms, and an imbalance in sediment organic carbon budgets? Chem. Rev. 107, 467-485.

Butterfield, N. J. (2009) Oxygen, animals and oceanic ventilation: an alternative view. Geobiology 7, 1-7.

Canfield, D. E. and Farquhar, J. (2009) Animal evolution, bioturbation, and the sulfate concentration of the oceans. Proc. Natl. Acad. Sci. U.S.A. 106, 8123-8127.

Canfield, D. E., Poulton, S. W., Knoll, A. H., Narbonne, G. M., Ross, G., Goldberg, T. and Strauss, H. (2008) Ferruginous conditions dominated later Neoproterozoic deep-water chemistry. Science 321, 949-952.

Canfield, D. E., Poulton, S. W. and Narbonne, G. M. (2007) Late-Neoproterozoic deep-ocean oxygenation and the rise of animal life. Science 315, 92-95.

Canfield, D. E., Raiswell, R. and Bottrell, S. (1992) The reactivity of sedimentary iron minerals toward sulfide. Am. J. Sci. 292, 659-683.

Clark, L. L., Ingall, E. D. and Benner, R. (1998) Marine phosphorus is selectively remineralized. Nature 393, 426.

Colman, A. S. And Holland, H. D. (2000) The global diagenetic flux of phosphorus from marine sediments to the oceans: redox sensitivity and the control of atmospheric oxygen levels. In Marine Authigenesis: From Global to Microbial, SEPM Special Publication No. 66. 53-75.

Colman, A. S., Mackenzie, F. T. and Holland, H. D. (1997) Redox stabilization of the atmosphere and oceans and marine productivity. Science $\mathbf{2 7 5}, 406-408$.

Dale, A. W., Sommer, S., Bohlen, L., Treude, T., Bertics, V. J., Bange, H. W., Pfannkuche, O., Schorp, T., Mattsdotter, M. and Wallmann, K. (2011) Rates and regulation of nitrogen cycling in seasonally hypoxic sediments during winter (Boknis Eck, SW Baltic Sea): sensitivity to environmental variables. Est. Coast. Shelf Sci. 95, 14-28.

Dale, A. W., Bertics, V. J., Treude, T., Sommer, S. and Wallmann, K. (2013) Modeling benthic-pelagic nutrient exchange processes and porewater distributions in a seasonally hypoxic sediment: evidence for massive phosphate release by Beggiatoa? Biogeosciences 10, 629-651, doi:10.5194/bg-10-629-2013.

Dale, A. W., Nickelsen L., Scholz, F., Hensen, C., Oschlies, A. and Wallmann, K. (2015a) A revised global estimate of dissolved iron fluxes from marine sediments. Glob. Biogeochem. Cy. 29, doi: $10.1002 / 2014$ GB005017.

Dale, A. W., Sommer, S., Lomnitz, U., Montes, I., Treude, T., Liebetrau, V., Gier, J. , Hensen, C., Dengler, M., Stolpovsky, K., Bryant, L. D. and Wallmann, K. (2015b) Organic carbon production, mineralisation and preservation on the Peruvian margin. Biogeosciences 12, 1537-1559.

Davelaar, D. (1993) Ecological significance of bacterial polyphosphate metabolism in sediments. Hydrobiologia 253, 179-192.

De Deckere, E., Tolhurst, T. J. and de Brouwer, J. F. C. (2001) Destabilization of cohesive intertidal sediments by infauna. Estuar. Coast. Shelf Sci. 53, 665-669. 
Delaney, M. L. (1998) Phosphorus accumulation in marine sediments and the oceanic phosphorus cycle. Glob. Biogeochem. Cy. 12, 563-572, doi:10.1029/98GB02263.

Demaison, G. J. and Moore, G. T. (1980) Anoxic environments and oil source bed genesis. Am. Assoc. Pet. Geol. Bull. 64, 1179-1209.

Devol, A. H. And Christensen, J. P. (1993) Benthic fluxes and nitrogen cycling in sediments of the continental margin of the eastern North Pacific. J. Mar. Res. 51, 345-372.

Diaz, J., Ingall, E., Benitez-Nelson, C., Paterson, D., de Jonge, M. D., McNulty, I. and Brandes, J. A. (2008) Marine polyphosphate: a key player in geologic phosphorus sequestration. Science 320, 652-655.

Diaz, J. M. and Ingall, E. D. (2010) Fluorometric quantification of natural inorganic polyphosphate. Environ. Sci. Technol. 44, 4665-4671.

Diaz, J. M., Ingall, E. D., Snow, S. D., Benitez-Nelson, C. R., Taillefert, M. and Brandes, J. A. (2012) Potential role of inorganic polyphosphate in the cycling of phosphorus within the hypoxic water column of Effingham Inlet, British Columbia. Glob. Biogeochem. Cy. 26, GB2040, doi:10.1029/2011GB004226.

Falkowski, P. G., Katz, M. E., Knoll. A. K., Quigg, A., Raven, J. A., Schofield, O. and Taylor, F. J. R. (2004) The evolution of modern eukaryotic phytoplankton. Science 305, 354-360.

Faul, K. L., Paytan, A. and Delaney, M. L. (2005) Phosphorus distribution in sinking oceanic particulate matter. Mar. Chem. 97, 307-333.

Filippelli, G. M. (2001) Carbon and phosphorus cycling in anoxic sediments of the Saanich Inlet, British Columbia. Mar. Geol. 174, 307-321.

Filippelli, G. M. and Delaney, M. L. (1996) Phosphorus geochemistry of equatorial Pacific sediments. Geochim. Cosmochim. Acta 60, 1479-1495.

Fossing, H., Ferdelman, T. G., and Berg, P. (2000) Sulfate reduction and methane oxidation in continental margin sediments influenced by irrigation (South-East Atlantic off Namibia). Geochim. Cosmochim. Acta 64, 897-910.

Froelich, P., Arthur, M. A., Burnett, W. C., Deakin, M., Hensley, V., Jahnke, R., Kaul, N., Kim, K. H., Roe, K., Soutar, A. and Vathakanon, C. (1988) Early diagenesis of organic matter in Peru continental margin sediments: Phosphorite precipitation. Mar. Geol. 80, 309-343.

Froelich, P. N., Bender, M. L., Luedtke, N. A., Heath, G. R. and DeVries, T. (1982) The marine phosphorus cycle. Am. J. Sci. 282, 474-511.

Froelich, P. N., Kim, K. H., Jahnke, R., Burnett, W. C., Soutar, A. and Deakin, M. (1983) Pore water fluoride in Peru continental margin sediments: Uptake from seawater. Geochim. Cosmochim. Acta 47, 1605-1612.

Froelich, P. N., Klinkhammer, G. P., Bender, M. L., Luedtke, N. A., Heath, G. R., Cullen, D. and Dauphin, P. (1979) Early oxidation of organic matter in pelagic sediments of the eastern equatorial Atlantic: suboxic diagenesis. Geochim. Cosmochim. Acta 43, 1075-1090.

Gachter, R. and Meyer, J. S. (1993) The role of microorganisms in mobilization and fixation of phosphorus in sediments. Hydrobiologia 253, 103-121.

Gachter, R., Meyer, J. S. and Mares, A. (1988) Contribution of bacteria to release and fixation of phosphorus in lake sediments. Limnol. Oceanogr. 33, 1542-1558.

Glud, R. N. (2008) Oxygen dynamics of marine sediments. Mar. Biol. Res. 4, 243-289.

Hartnett H. E., Keil R. G., Hedges J. I. and Devol A. H. (1998) Influence of oxygen exposure time on organic carbon preservation in continental margin sediments. Nature 391, 572-574.

Hedges, J. I., Hu, F. S., Devol, A. H., Hartnett H. E., Tsamakis, E. and Keil, R. G. (1999) Sedimentary organic matter preservation: A test for selective degradation under oxic conditions. Am. J. Sci. 299, 529-555.

Houben, G. J. (2003) Iron oxide incrustations in wells. Part 1: genesis, mineralogy and geochemistry. App. Geochem. 18, 927-939.

Hupfer, M., Rube, B. and Schmieder, P. (2004) Origin and diagenesis of polyphosphate in lake sediments: A P31-NMR study. Limnol. Oceanogr. 49, 1-10.

Ingall, E. and Jahnke, R. (1994) Evidence for enhanced phosphorus regeneration from marine sediments overlain by oxygen depleted waters. Geochim. Cosmochim. Acta 58, 2571-2575. 1994.

Ingall, E. and Jahnke, R. (1997) Influence of water-column anoxia on the elemental fractionation of carbon and phosphorus during sediment diagenesis. Mar. Geol. 139, 219-229.

Ingall, E., Kolowith, L., Lyons, T. and Hurtgen, M. (2005) Sediment carbon, nitrogen and phosphorus cycling in an anoxic fjord, Effingham Inlet, British Columbia. Am. J. Sci. 305, 240-258.

Ingall, E. D., Bustin, R. M. and Van Cappellen, P. (1993) Influence of water column anoxia on the burial and preservation of carbon and phosphorus in marine shales. Geochim. Cosmochim. Acta 57, 303-316.

Ingall, E. D. and Van Cappellen, P. (1990) Relation between sedimentation rate and burial of organic phosphorus and organic carbon in marine sediments. Geochim. Cosmochim. Acta 54, 373-386.

Jahnke, R. A., Emerson, S. R., Roe, K. K., and Burnett, W. C. (1983) The present day formation of apatite in Mexican continental margin sediments. Geochim. Cosmochim. Acta 47, 259-266. 
Jennings, S., Melin, F., Blanchard, J. L., Forster, R. M., Dulvy, N. K. and Wilson, R. W. (2008) Global-scale predictions of community and ecosystem properties from simple ecological theory. Proc. R. Soc. B. 275, 1375-1383.

Jensen, H. S., Mortensen P. B., Andersen F. O. and Rasmussen E. (1995) Phosphorus cycling in a coastal marine sediment, Aarhus Bay, Denmark. Limnol. Oceanogr. 40, 908-917.

Jensen, H. S. and Thamdrup, B. (1993) Iron-bound phosphorus in marine sediments as measured by bicarbonate-dithionite extraction. Hydrobiologia 253, 47-59.

Jilbert, T., Slomp, C. P., Gustafsson, B. G. and Boer, W. (2011) Beyond the Fe-P-redox connection: preferential regeneration of phosphorus from organic matter as a key control on Baltic Sea nutrient cycles. Biogeosciences 8, 1699-1720.

Johnston, D. T., Poulton, S. W., Goldberg, T., Sergeev, V. A., Podkovyrov, V., Vorob'eva, N. G. , Bekker, A. and Knoll, A. H. (2012) Late Ediacaran redox stability and metazoan evolution. Earth Planet. Sci. Lett. 335336, 25-35. 2012.

Jordan, T. E., Cornwell, J. C., Boynton, W. R. and Anderson, J. T. (2008) Changes in phosphorus biogeochemistry along an estuarine salinity gradient: The iron conveyer belt. Limnol. Oceanogr. 53, 172184.

Kendall, B., Anbar, A. D., Kappler, A. and Konhauser, K. O. (2012) The global iron cycle. In Fundamentals of Geobiology (eds A. H. Knoll, D. E. Canfield and K. O. Konhauser), John Wiley and Sons, Ltd, Chichester, UK. doi: 10.1002/9781118280874.ch6.

Kraal, P., Slomp, C. P., Reed, D. C., Reichart, G.-J. and Poulton, S. W. (2012) Sedimentary phosphorus and iron cycling in and below the oxygen minimum zone of the northern Arabian Sea. Biogeosciences 9, 2603-2624.

Kraal, P., Bostick, B. C., Reichart, G.-J. and Slomp, C. P. (2015) Characterization of phosphorus species in sediments from the Arabian Sea oxygen minimum zone: Combining sequential extractions and X-ray spectroscopy. Mar. Chem. 168, 1-8.

Krajewski K. P., Van Cappellen P., Trichet J., Kuhn O., Lucas J., Martin-Algarra A., Prévot L., Tewari V. C., Gaspar L., Knight R. I. and Lamboy M. (1994) Biological processes and apatite formation in sedimentary environments. Eclogae Geol. Helv. 87, 701-745.

Krom, M. D. and Berner, R. A. (1981) The diagenesis of phosphorus in a nearshore marine sediment. Geochim. Cosmochim. Acta 45, 207-216.

Kulaev, I. and Kulakovskaya, T. (2000) Polyphosphate and phosphate pump. Ann. Rev. Microbiol. 54, 709-734.

Lebo, M. E. Particle-bound phosphorus along an urbanized coastal plain estuary. Mar. Chem. 34, 225-246. 1991.

Lenton, T. M., Boyle, R. A., Poulton, S. W., Shields-Zhou, G. A. and Butterfield, N. J. (2014) Co-evolution of eukaryotes and ocean oxygenation in the Neoproterozoic era. Nat. Geosci. 7, 257-265.

Lenton, T. M. and Watson, A. J. (2000) Redfield revisited 2. What regulates the oxygen content of the atmosphere? Glob. Biogeochem. Cy. 14, 249-268.

Levin, L. A. and Gage, J. D. (1998) Relationships between oxygen, organic matter and the diversity of bathyal macrofauna. Deep-Sea Res. Part II 45, 129-163.

Li, C., Love, G. D., Lyons, T. W., Fike, D. A., Sessions, A. L. and Chu, X. (2010) A stratified redox model for the Ediacaran ocean. Science 328, 80-83.

Lijklema, L. (1980) Interaction of orthophosphate with iron(III) and aluminum hydroxides. Env. Sci. Technol. 14, 537-541.

Lucotte, M. and D’Anglejan, B. (1983) Forms of phosphorus and phosphorus iron relationships in the suspended matter of the St. Lawrence estuary. Canad. J. Earth Sci. 20, 1880-1890.

Lyons, T. W., Reinhard, C. T., Love, G. D. and Xiao, S. (2012) Geobiology of the Proterozoic Eon. In Fundamentals of Geobiology (eds A. H. Knoll, D. E. Canfield and K. O. Konhauser), John Wiley and Sons, Ltd, Chichester, UK. doi: 10.1002/9781118280874.ch20.

Lyons, T. W., Reinhard, C. T. and Planavsky, N. J. (2014) The rise of oxygen in Earth's early ocean and atmosphere. Nature 506, 307-315.

Maloof, A. C., Porter, S. M., Moore, J. L., Dudas, F. O., Bowring, S. A., Higgins, J. A., Fike, D. A. and Eddy, M. P. (2010) The earliest Cambrian record of animals and ocean geochemical change. Geolog. Soc. Am. Bull. 122, 1731-1774.

Meile, C. and Van Cappellen, P. (2005) Particle age distributions and $\mathrm{O}_{2}$ exposure times: Timescales in bioturbated sediments. Glob. Biogeochem. Cy. 19, GB3013, doi:10.1029/2004GB002371.

Mermillod-Blondin, F. and Rosenberg, R. (2006) Ecosystem engineering: the impact of bioturbation on biogeochemical processes in marine and freshwater benthic habitats. Aquat. Sci. 68, 434-442.

Meysman, F. J. R., Boudreau, B. P., and Middelburg, J. J. (2003) Relations between local, nonlocal, discrete and continuous models of bioturbation. J. Mar. Res. 61, 391-410.

Meysman, F. J. R., Middelburg, J. J. and Heip, C. H. R. (2006) Bioturbation: a fresh look at Darwin's last idea. Trends Ecol. Evol. 21, 688-695. 
Middelburg, J. J. (1989) A simple rate model for organic matter decomposition in marine sediments. Geochim. Cosmochim. Acta 53, 1577-1581.

Middelburg, J. J. and Levin, L. A. (2009) Coastal hypoxia and sediment biogeochemistry. Biogeosciences 6, 1273-1293.

Mángano, M. G. and Buatois, L. A. (2015) Decoupling of body-plan diversification and ecological structuring during the Ediacaran-Cambrian transition: evolutionary and geobiological feedbacks. Proc. R. Soc. B. 281, 20140038.

Noffke, A., Hensen, C., Sommer, S., Scholz, F., Bohlen, L., Mosch, T., Graco, M. and Wallmann, K. (2012) Benthic iron and phosphorus fluxes across the Peruvian oxygen minimum zone. Limnol. Oceanogr. 57, 851867.

Och, L. M. and Shields-Zhou, G. A. (2012) The Neoproterozoic oxygenation event: Environmental perturbations and biogeochemical cycling. Earth-Sci. Rev. 110, 26-57.

Papineau, D. (2010) Global biogeochemical changes at both ends of the Proterozoic: insights from phosphorites. Astrobiology 10, 165-181.

Paytan, A., Cade-Menun, B. J., McLaughlin, K. and Faul, K. L. (2003) Selective phosphorus regeneration of sinking marine particles: evidence from ${ }^{31} \mathrm{P}-\mathrm{NMR}$. Mar. Chem. 82, 55-70.

Paytan, A. and McLaughlin, K. (2007) The oceanic phosphorus cycle. Chemical Reviews 107, 563-576.

Peters, S. E. and Gaines, R. R. (2012) Formation of the 'Great Unconformity' as a trigger for the Cambrian explosion. Nature 484, 363-366.

Poulton, S. W. and Canfield, D. E. (2006) Co-diagenesis of iron and phosphorus in hydrothermal sediments from the southern East Pacific Rise: Implications for the evaluation of paleoseawater phosphate concentrations. Geochim. Cosmochim. Acta 70, 5883-5898.

Poulton, S. W., Krom, M. D. and Raiswell, R. (2004) A revised scheme for the reactivity of iron (oxyhydr)oxide minerals towards dissolved sulfide. Geochim. Cosmochim. Acta 68, 3703-3715.

Reed, D. C., Slomp, C. P. and Gustafsson, B. G. (2011) Sedimentary phosphorus dynamics and the evolution of bottom-water hypoxia: A coupled benthic-pelagic model of a coastal system. Limnol. Oceanogr. 56, 10751092.

Renz, J. R. and Forster, S. (2014) Effects of bioirrigation by the three sibling species of Marenzelleria spp. on solute fluxes and porewater nutrient profiles. Mar. Ecol. Prog. Ser. 505, 145-159.

Robbins, J. A. (1986) A model for particle-selective transport of tracers in sediments with conveyor belt deposit feeders. J. Geophys. Res. 91, 8542-8558.

Ruttenberg, K. C. (2014) The global phosphorus cycle. In Treatise on Geochemistry Volume 10, (eds. H. D. Holland and K. K. Turekian), Elsevier, p 499-558.

Ruttenberg, K. C. and Berner, R. A. (1993) Authigenic apatite formation and burial in sediments from nonupwelling, continental margin environments. Geochim. Cosmochim. Acta 57, 991-1007.

Ruttenberg, K. C. and Goni, M. A. (1997) Phosphorus distribution, C:N:P ratios, and $\delta^{13} \mathrm{C}_{\mathrm{OC}}$ in arctic, temperate, and tropical coastal sediments: Tools for characterizing bulk sedimentary organic matter. Mar. Geol. 139, 123-145.

Saltzman, M. R., Edwards, E. T., Adrain, J. M. And Westrop, S. R. (2015) Persistent oceanic anoxia and elevated extinction rates separate the Cambrian and Ordovician radiations. Geology, 43, 807-810.

Sannigrahi, P. and Ingall, E. (2005) Polyphosphates as a source of enhanced P fluxes in marine sediments overlain by anoxic waters: Evidence from ${ }^{31} \mathrm{P}$ NMR. Geochem. Trans. 6, 52.

Sarmiento, J. L. and Gruber, N. (2006) Ocean Biogeochemical Dynamics. Princeton University Press, Princeton, $526 \mathrm{pp}$.

Schenau, S. J. and de Lange, G. J. (2001) Phosphorus regeneration vs. burial in sediments of the Arabian Sea. Mar. Chem. 75, 201-217.

Schenau, S. J., Reichart, G. J. and de Lange, G. J. (2005) Phosphorus burial as a function of paleoproductivity and redox conditions in Arabian Sea sediments. Geochim. Cosmochim. Acta 69, 919-931.

Schuffert, J. D., Jahnke, R. A., Kastner, M., Leather, J., Sturz, A. and Wing, M. R. (1994) Rates of formation of modern phosphorite off western Mexico. Geochim. Cosmochim. Acta 58, 5001-5010.

Schulz, H. N. and Schulz, H. D. (2005) Large sulfur bacteria and the formation of phosphorite. Science $\mathbf{3 0 7}$, 416-418.

Shapiro, J. (1967) Induced rapid release and uptake of phosphate by microorganisms. Science 155, 1269-1271.

Shen, Y. N., Zhang, T. G. and Hoffman, P. F. (2008) On the coevolution of Ediacaran oceans and animals. Proc. Natl. Acad. Sci. U.S.A. 105, 7376-7381.

Slomp, C. P. (2011) Phosphorus cycling in the estuarine and coastal zones: sources, sinks, and transformations. In Treatise on Estuarine and Coastal Science 5 (eds. E. Wolanksi and D. McLusky), 201-229.

Slomp, C. P., Epping, E. H. G., Helder, W. and Van Raaphorst, W. (1996) A key role for iron-bound phosphorus in authigenic apatite formation in North Atlantic continental platform sediments. J. Mar. Res. 54, 1179-1205. 
Slomp, C. P., Thomson, J. and de Lange, G. J. (2004) Controls on phosphorus regeneration and burial during formation of eastern Mediterranean sapropels. Mar. Geol. 203, 141-159.

Slomp, C. P. and Van Cappellen, P. (2007) The global marine phosphorus cycle: sensitivity to oceanic circulation. Biogeosciences 4, 155-171.

Smith, J. N., Boudreau, B. P. And Noshkin, V. (1986) Plutonium and ${ }^{210} \mathrm{~Pb}$ distributions in northeast Atlantic sediments: subsurface anomalies caused by nonlocal mixing. Earth Planet. Sci. Lett., 81, 15-28.

Spiteri, C., Van Cappellen, P. and Regnier, P. (2008) Surface complexation effects on phosphate adsorption to ferric iron oxyhydroxides along $\mathrm{pH}$ and salinity gradients in estuaries and coastal aquifers. Geochim. Cosmochim. Acta 72, 3431-3445.

Steenbergh, A. K., Bodelier, P. L. E., Heldal, M., Slomp, C. P., Laanbroek, H. J. (2012) Does microbial stoichiometry modulate eutrophication of aquatic ecosystems? Env. Microbiol. 15, 1572-1579.

Suess, E. (1981) Phosphate regeneration from sediments of the Peru continental margin by dissolution of fish debris. Geochim. Cosmochim. Acta 45, 577-588.

Sun, M. Y., Aller, R. C., Lee, C., \& Wakeham, S. G. (2002) Effects of oxygen and redox oscillation on degradation of cell-associated lipids in surficial marine sediments. Geochim. Cosmochim. Acta 66, 20032012.

Sundby, B., Gobeil, C., Silverberg, N. and Mucci, A. (1992) The phosphorus cycle in coastal marine sediments. Limnol. Oceanogr. 37, 1129-1145.

Tarhan, L. G. and Droser, M. L. (2014) Widespread delayed mixing in early to middle Cambrian marine shelfal settings. Palaeogeogr. Palaeoclimatol. Palaeoecol. 399, 310-322.

Tarhan, L. G., Droser, M. L., Planavsky, N. J. and Johnston, D. T. (2015) Protracted development of bioturbation through the early Palaeozoic Era. Nat. Geosci. 8, 865-869.

Thamdrup, B., Dalsgaard, T., and Revsbech, N. P. (2012) Widespread functional anoxia in the oxygen minimum zone of the Eastern South Pacific. Deep Sea Research Part I: Oceanographic Research Papers 65, 36-45.

Van Cappellen, P. and Berner, R. A. (1988) A mathematical model for the early diagenesis of phosphorus and fluorine in marine sediments; apatite precipitation. Am. J. Sci. 288, 289-333.

Van Cappellen, P. and Ingall, E. D. (1994) Benthic phosphorus regeneration, net primary production, and ocean anoxia: A model of the coupled marine biogeochemical cycles of carbon and phosphorus. Paleoceanography 9, 677-692.

Van Cappellen P. and Ingall, E. D. (1997) Redox stabilization of the atmosphere and oceans and marine productivity - Response. Science $\mathbf{2 7 5}, \mathbf{4 0 7 - 4 0 8 .}$

Van Cappellen, P. and Ingall, E. D. (1996) Redox stabilization of the atmosphere and oceans by phosphoruslimited marine productivity. Science 271.

van der Zee, C., Roberts, D. R., Rancourt, D. G. and Slomp, C. P. (2003) Nanogoethite is the dominant reactive oxyhydroxide phase in lake and marine sediments. Geology 31, 993-996.

Wallmann, K. (2014) Is late Quaternary climate change governed by self-sustained oscillations in atmospheric CO2? Geochim. Cosmochim. Acta 132, 413-439.

Wallmann, K. (2010) Phosphorus imbalance in the global ocean? Glob. Biogeochem. Cy. 24, GB4030, doi:10.1029/2009GB003643.

Westrich, J. T. and Berner, R. A. (1984). The role of sedimentary organic matter in bacterial sulfate reduction: the G-model tested. Limnol. Oceanogr. 29, 236-249. 
1011 Fig. 1. Conceptual P cycle in fine-grained, oxic (bioturbated and bioirrigated) continental margin 1012 sediments outside of oxygen minimum zones. White squares and circles denote solids and solutes, 1013 respectively. Particulate $\mathrm{P}$ is added to the sediment as $\mathrm{P}_{\text {org }}$ and $\mathrm{FeP}$. $\mathrm{PO}_{4}{ }^{3-}$ released to the porewater 1014 from these phases is free to be transported out of the sediment by diffusion and bioirrigation. $\mathrm{PO}_{4}{ }^{3-}$ 1015 can also be re-precipitated into authigenic FeP and CFA. The extended model considers P cycling by microorganisms (blue arrows). Dissolved $\mathrm{PO}_{4}{ }^{3-}$ can be assimilated into an intracellular polyphosphate pool $\left(\mathrm{P}_{\text {poly }}\right)$. A fraction $\left(f_{\text {poly }}\right)$ of $\mathrm{P}_{\text {poly }}$ is transformed into an unreactive particulate organic $\mathrm{P}$ phase $\left(\mathrm{P}_{\text {org- }}\right.$ U) with the remainder $\left(1-f_{\text {poly }}\right)$ shunted back to the bulk $\mathrm{P}_{\text {org }}$ pool. If $\mathrm{P}_{\text {poly }}$ is mixed or buried below the aerobic sediment layers it is rapidly hydrolyzed back to $\mathrm{PO}_{4}{ }^{3-}$. The black bars on the right schematically indicate the spatial separation of organic matter respiration by electron acceptors with depth in the bioturbated layer. See Table S4 for stoichiometries of reactions, R.

Fig. 2. Simulated rates of $P$ turnover in (a) oxic and (b) anoxic sediments in modern shelf sediments $\left(\mu \mathrm{mol} \mathrm{m} \mathrm{m}^{-2}\right) . \mathrm{P}_{\text {reac }}$ burial fluxes are calculated at $100 \mathrm{~cm}$. The relative magnitude of the fluxes is indicated schematically by the arrow thicknesses.

1026

Fig. 3. Simulated concentrations in modern shelf sediments. (a) Dissolved oxygen, (b) nitrate + nitrite, (c) phosphate, (d) organic $\mathrm{C}$, (e) organic $\mathrm{P}$ (including $\mathrm{P}_{\text {org-U}}$ ), (f) iron-associated $\mathrm{P}$, (g) carbonate fluorapatite, and (h) total reactive P. Green and black curves represent scenarios with oxic and anoxic bottom waters, respectively. Dashed red curves show simulation results for oxic sediments without the microbial P pump and thus the effect of animals only (red star in Fig. 4a). The dashed blue curves examine the effect of microbial P without bioturbation and bioirrigation (blue star in Fig. 4a). Despite preferential mineralization of $\mathrm{P}_{\text {org }}$ in oxic sediment layers, $\mathrm{P}_{\text {org }}$ concentrations are highest in the oxic scenario due to synthesis of microbial $\mathrm{P}_{\text {org }}$. $\mathrm{C}_{\text {org }}$ concentrations are, in contrast, lower in oxic sediments. $\mathrm{P}_{\text {org }}$ is absent below the bioturbation zone in the simulation without microbial $\mathrm{P}$ synthesis. All geochemical profiles are shown in the Electronic Annex. Note different depth scales.

Fig. 4. Simulated steady state $\mathrm{P}_{\text {reac }}$ burial flux for sediments over a range of bottom water $\mathrm{O}_{2}$ concentrations. (a) Modern sediments. Fluxes using the baseline model parameters (Table 2) are shown as black curves with circles, and the grey shaded area shows $\mathrm{P}$ burial for the full range of $f_{\text {poly }}$

1041 (0 to 1). Results are also shown for a deeper sediment mixing and burrowing (doubling of parameters $z_{b t}$ and $z_{b i o}$ ), and for more intense mixing and burrowing (doubling of parameters $D_{b}(0)$ and $\alpha(0)$ ). The dashed red curve shows P burial without the microbial P pump, whereas the dashed blue curve shows results where bioturbation and bioirrigation are turned off. The stars correspond to the respective sediment profiles in Fig. 3. The green circle shows the anoxic baseline simulation with a lower 
1046 porosity (see text). (b) Early Paleozoic sediments. P burial fluxes using the parameters in Table 2 are 1047 shown as the black curve and the dashed blue curve is the result without bioturbation and 1048 bioirrigation. The red curve is $\mathrm{P}$ burial with a deeper $2 \mathrm{~cm}$ sediment mixed depth, tentatively 1049 applicable to the late Cambrian / Ordovician shelf $\left(z_{b t}=1 \mathrm{~cm}, z_{b i o}=1 \mathrm{~cm}, D_{b}(0)=5 \mathrm{~cm}^{2} \mathrm{yr}^{-1}, \alpha(0)=50\right.$ $\left.1050 \mathrm{y}^{-1}\right)$. The arrows schematically indicate the expected trajectory of $\mathrm{P}$ burial following the radiation of 1051 deposit feeders and burrowing fauna with bottom water $\mathrm{O}_{2}$ concentrations believed to characterize the 1052 early Paleozoic (Canfield et al., 2007).

1053

1054 Fig. 5. Organic phosphorus mineralization rate (sum of $R_{1}$ to $R_{7}$, Table S5) in oxic sediments 1055 inhabited by fauna (green curve) and oxic sediments without fauna (dashed blue curves). Bioturbation 1056 leads to lower rates at the surface and higher rates towards the base of the bioturbated zone, favoring 1057 the sequestration of $\mathrm{P}$ into authigenic phases including microbial $\mathrm{P}$. The bottom water $\mathrm{O}_{2}$ 1058 concentration is $150 \mu \mathrm{M}$ in both cases. 
Table 1. Observations of $\mathrm{C}$ and $\mathrm{P}$ geochemistry in oxic and anoxic margin sediments.

\begin{tabular}{lll}
\hline & Oxic & Anoxic \\
\hline $\mathrm{C}_{\text {org }}: \mathrm{P}_{\text {org }}$ & $30-115^{\mathrm{a}}$ & $200-700^{\mathrm{b}}$ \\
$\mathrm{C}_{\text {org }}: \mathrm{P}_{\text {reac }}$ & $21^{\mathrm{c}}$ & $54-161^{\mathrm{c}}$ \\
$\mathrm{C}_{\text {org }}$ burial efficiency $(\mathrm{CBE}, \%)$ & $25 \pm 10^{\mathrm{d}}$ & $>40^{\mathrm{e}}$ \\
$\mathrm{P}_{\text {org }}$ burial efficiency $(\mathrm{PBE}, \%)$ & $20-40^{\mathrm{f}}$ & $<2-11^{\mathrm{g}}$ \\
$(\mathrm{C}: \mathrm{P})_{\text {REG }}{ }^{\mathrm{h}}$ & $118 \pm 24^{\mathrm{i}}$ & $<70^{\mathrm{j}}$ \\
\hline
\end{tabular}

$1061{ }^{a}$ From the data corresponding to 'oxic sites' in Fig. 3 of Slomp and Van Cappellen (2007).

$1062{ }^{b}$ From the data corresponding to 'low oxygen and anoxic sites' in Fig. 3 of Slomp and Van Cappellen (2007), as 1063 well as data from the anoxic Arabian Sea oxygen minimum zone from Kraal et al. (2012). Values exceeding 10641000 observed in the paleo record are rare in modern sediments.

$1065{ }^{\mathrm{c}}$ Slomp et al. (2004)

$1066{ }^{\mathrm{d}}$ Literature data show that CBE depends non-linearly on the sediment mass accumulation rate (e.g. Burdige, 1067 2007) and, possibly, the availability of dissolved oxygen. A mass accumulation rate of $0.075 \mathrm{~g} \mathrm{~cm}^{-2} \mathrm{yr}^{-1} \mathrm{can} \mathrm{be}^{-3}$ 1068 calculated for a typical upper slope / shelf setting using the formula $\rho \cdot(1-\varphi) \cdot \omega_{a c c}$ where $\rho\left(2.5 \mathrm{~g} \mathrm{~cm}^{-3}\right)$ is the 1069 density of sediment particles, and $\varphi(0.7)$ and $\omega_{\text {acc }}\left(0.1 \mathrm{~cm} \mathrm{yr}^{-1}\right)$ are the porosity and sedimentation rate of 1070 compacted sediments, respectively. For oxygenated bottom waters $\left(>20 \mu \mathrm{M} \mathrm{O} \mathrm{O}_{2}\right)$, this mass accumulation rate 1071 corresponds to a CBE of around $25 \%$ (Dale et al., 2015b).

$1072 \quad$ As footnote ${ }^{\mathrm{d}}$, for $<20 \mu \mathrm{M} \mathrm{O}_{2}$

$1073{ }^{\mathrm{f}}$ Data on PBE in oxic, bioturbated sediments are scarce and there is high uncertainty in this value. PBE can be 1074 estimated using the $\mathrm{CBE}$ and $\mathrm{C}_{\text {org }}: \mathrm{P}_{\text {org }}$ burial ratios for which more data is available: $\mathrm{PBE}_{\mathrm{OX}}=\frac{\mathrm{PBE}_{\mathrm{AN}} \cdot \mathrm{CBE}_{\mathrm{OX}} \cdot\left(\mathrm{C}_{\text {org }}: \mathrm{P}_{\mathrm{org}}\right)_{\mathrm{AN}}}{\mathrm{CBE}_{\mathrm{AN}} \cdot\left(\mathrm{C}_{\mathrm{Org}}: \mathrm{P}_{\text {org }}\right)_{\mathrm{OX}}}$, where subscripts ' $\mathrm{OX}$ ' and 'AN' denote oxic and anoxic sediments, respectively. Assuming average values for $\mathrm{CBE}_{\mathrm{AN}}, \mathrm{PBE}_{\mathrm{AN}}$ and $\left(\mathrm{C}_{\mathrm{org}}: \mathrm{P}_{\mathrm{org}}\right)_{\mathrm{AN}}$ of $50 \%, 7 \%$ and 400 , respectively, and $\mathrm{CBE}_{\mathrm{OX}}$ and $\left(\mathrm{C}_{\mathrm{org}}: \mathrm{P}_{\mathrm{org}}\right)_{\mathrm{OX}}$ burial ratios of $25 \%$ and 50 (respectively), $\mathrm{PBE}_{\mathrm{OX}}$ is $28 \pm 14 \%$, hence the proposed range of $20-40$. Notwithstanding the uncertainty arising from the input parameters, PBE in oxic sediments is at least a factor of $2-4$ that in anoxic sediments. For comparison, Jensen et al. (1995) calculated a PBE of $29-35 \%$ in oxic Aarhus Bay sediments, whereas Ingall and Jahnke (1994) reported lower PBE in oxic sediments ranging from 6 to $23 \%$ based on a few observations on the continental slope.

${ }^{\mathrm{g}}$ For oxygen deficient bottom waters $\left(<20 \mu \mathrm{M} \mathrm{O}_{2}\right.$ ) (Schenau et al., 2000; Slomp et al., 2004; Ingall and Jahnke, 1994)

${ }^{\mathrm{h}}$ Benthic regeneration ratio $=$ DIC flux $/ \mathrm{PO}_{4}{ }^{3-}$ flux at sediment surface determined in situ using benthic chambers. It is important to point out that Colman and Holland (2000) caution that benthic phosphate fluxes, and indeed dissolved inorganic carbon fluxes, may exhibit seasonal variability. For the present study, we note these concerns but lay them to one side, and consider that $(\mathrm{C}: \mathrm{P})_{\mathrm{REG}}$ ratios are indicative of steady state or seasonally-averaged conditions.

${ }^{\mathrm{i}}$ Using the empirical transfer function of Wallmann (2010).

${ }^{j}$ Values for anoxic bottom waters on the Peruvian margin range from 4 to 68 (Noffke et al., 2012). The empirical function of Wallmann (2010) based on in situ flux measurements predicts a value of $11 \pm 24$ for nearanoxic conditions, although the full range of values for anoxic waters is very similar to the Peruvian margin. Sannigrahi and Ingall (2005) report a value of 39 for an anoxic site in Effingham Inlet. 

anoxic and early Paleozoic (Pz) settings that differ from these are also given. Parameter sources are given in Table S3.

\begin{tabular}{|c|c|c|c|}
\hline Description & & Value & \\
\hline & Oxic & Anoxic & $\mathrm{Pz}$ \\
\hline Sediment accumulation rate, $\omega_{a c c}\left(\mathrm{~cm} \mathrm{yr}^{-1}\right)$ & 0.1 & & \\
\hline Surface sediment porosity, $\varphi(0)(-)$ & 0.9 & & \\
\hline Bioturbation coefficient at sediment surface, $D_{b}(0)\left(\mathrm{cm}^{2} \mathrm{yr}^{-1}\right)^{\mathrm{a}}$ & 28 & 0.2 & 5 \\
\hline Bioturbation halving depth, $z_{b t}(\mathrm{~cm})$ & 3 & & 0.25 \\
\hline Bioirrigation coefficient at sediment surface, $\alpha(0)\left(\mathrm{yr}^{-1}\right)^{\mathrm{a}}$ & 465 & 4 & 50 \\
\hline Bioirrigation attenuation coefficient, $z_{b i o}(\mathrm{~cm})$ & 2 & & 1 \\
\hline Average lifetime of the reactive $\mathrm{C}_{\mathrm{org}}$ components, $a$ (yr) & $3 \times 10^{-4}$ & & \\
\hline Shape of gamma distribution for $\mathrm{C}_{\text {org }}$ mineralization, $v(-)$ & 0.05 & & \\
\hline Rate constant for precipitation of apatite, $k_{29}\left(\mathrm{yr}^{-1}\right)$ & 1 & & \\
\hline Rate constant for polyphosphate synthesis, $k_{30}\left(\mathrm{M}^{-1} \mathrm{yr}^{-1}\right)$ & $3 \times 10^{7}$ & & \\
\hline Rate constant for polyphosphate hydrolysis, $k_{31}\left(\mathrm{yr}^{-1}\right)$ & 50 & & \\
\hline Rate constant for transformation of $\mathrm{P}_{\text {poly }}$ to $\mathrm{P}_{\text {org }}, k_{32}\left(\mathrm{yr}^{-1}\right)$ & 50 & & \\
\hline Rate constant for transformation of $\mathrm{P}_{\text {poly }}$ to $\mathrm{P}_{\text {org-U }}, k_{33}\left(\mathrm{yr}^{-1}\right)$ & 50 & & \\
\hline Fraction of $\mathrm{P}_{\text {poly }}$ converted to $\mathrm{P}_{\text {org-U }}, f_{\text {poly }}(-)$ & 0.25 & & \\
\hline $\mathrm{Fe}: \mathrm{P}$ ratio in allochthonous $\mathrm{Fe}_{\mathrm{HR}}, \varepsilon_{\text {all }}\left(\mathrm{mol} \mathrm{Fe}(\mathrm{mol} \mathrm{P})^{-1}\right)$ & 25 & & \\
\hline $\mathrm{Fe}: \mathrm{P}$ ratio in authigenic $\mathrm{Fe}_{\mathrm{HR}}, \varepsilon_{\text {aut }}\left(\mathrm{mol} \mathrm{Fe}(\mathrm{mol} \mathrm{P})^{-1}\right)$ & 10 & & \\
\hline $\mathrm{Fe}: \mathrm{P}$ ratio in $\mathrm{Fe}_{\mathrm{MR}}$ recrystallized from $\mathrm{Fe}_{\mathrm{HR}}, \varepsilon_{\text {age }}\left(\mathrm{mol} \mathrm{Fe}(\mathrm{mol} \mathrm{P})^{-1}\right)$ & 40 & & \\
\hline Equilibrium $\mathrm{PO}_{4}{ }^{3-}$ concentration for CFA precipitation, $C_{e q}(\mu \mathrm{M})$ & 10 & & \\
\hline Atomic $\mathrm{P}-\mathrm{C}$ ratio in deposited organic matter, $r_{P C}\left(\mathrm{~mol} \mathrm{P}(\mathrm{mol} \mathrm{C})^{-1}\right)$ & $1 / 106$ & & \\
\hline Acceleration factor for aerobic (relative to anaerobic) $\mathrm{C}_{\text {org }}$ degradation, fox $C(-)$ & 2 & & \\
\hline Acceleration factor for aerobic $\mathrm{P}_{\text {org }}$ degradation relative to $\mathrm{C}_{\text {org }}$, foxP $(-)$ & 2 & & \\
\hline Acceleration factor for anaerobic $\mathrm{P}_{\text {org }}$ degradation relative to $\mathrm{C}_{\mathrm{org}}$, fanox $P(-)$ & 2 & & \\
\hline Bottom water concentration of $\mathrm{O}_{2}(\mu \mathrm{M})$ & 150 & 0.1 & Variable $^{\mathrm{b}}$ \\
\hline Bottom water concentration of $\mathrm{NO}_{3}^{-}(\mu \mathrm{M})$ & 35 & & \\
\hline Bottom water concentration of $\mathrm{SO}_{4}^{2-}(\mu \mathrm{M})$ & 28000 & & 3000 \\
\hline Bottom water concentration of $\mathrm{Fe}^{2+}(\mu \mathrm{M})$ & 0 & & \\
\hline Bottom water concentration of $\mathrm{PO}_{4}^{3-}(\mu \mathrm{M})$ & 0 & & \\
\hline Bottom water concentration of $\mathrm{H}_{2} \mathrm{~S}(\mu \mathrm{M})$ & 0 & & \\
\hline Seafloor flux of $\mathrm{C}_{\mathrm{org}}\left(\mathrm{mmol} \mathrm{cm} \mathrm{yr}^{-1}\right)$ & 0.34 & & \\
\hline 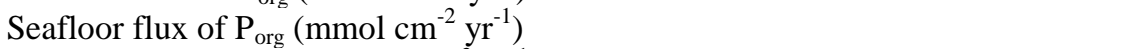 & $0.34 / r_{C P}$ & & \\
\hline Seafloor flux of $\mathrm{Fe}_{\mathrm{HR}}\left(\mathrm{mmol} \mathrm{cm} \mathrm{cm}^{-2} \mathrm{yr}^{-1}\right)$ & 0.011 & & \\
\hline Seafloor flux of $\mathrm{P}$ associated with $\mathrm{Fe}_{\mathrm{HR}}\left(\mathrm{mmol} \mathrm{cm} \mathrm{cr}^{-1}\right)$ & $0.011 / / \varepsilon_{\text {all }}$ & & \\
\hline Seafloor flux of CFA $\left(\mathrm{mmol} \mathrm{cm} \mathrm{cr}^{-1}\right)$ & 0 & & \\
\hline Seafloor flux of $\mathrm{P}_{\text {poly }}\left(\mathrm{mmol} \mathrm{cm} \mathrm{cm}^{-2} \mathrm{yr}^{-1}\right)$ & 0 & & \\
\hline Seafloor flux of $\mathrm{P}_{\text {org-U }}\left(\mathrm{mmol} \mathrm{cm} \mathrm{yr}^{-2} \mathrm{yr}^{-1}\right)$ & 0 & & \\
\hline
\end{tabular}


Table 3. Modelled C and P geochemistry in modern oxic and anoxic shallow margin sediments from the simulations that include the microbial P loop.

1106

1107

1108

1109

1110

\begin{tabular}{|c|c|c|}
\hline & Oxic & Anoxic \\
\hline $\mathrm{C}_{\text {org }} / \mathrm{P}_{\text {org }}$ burial ratio ${ }^{\mathrm{a}, \mathrm{b}}$ & 73 & 497 \\
\hline $\mathrm{C}_{\text {org }} / \mathrm{P}_{\text {reac }}$ burial ratio ${ }^{\mathrm{a}}$ & 44 & 196 \\
\hline $\mathrm{C}_{\text {org }}$ burial efficiency $(\mathrm{CBE}, \%)^{\mathrm{a}}$ & 16 & 47 \\
\hline $\mathrm{P}_{\text {org }}$ burial efficiency $(\mathrm{PBE}, \%)^{\mathrm{a}, \mathrm{b}}$ & 24 & 10 \\
\hline Inorganic carbon-to-phosphorus regeneration ratio, $(\mathrm{C}: \mathrm{P})_{\mathrm{REG}}$ & 116 & 63 \\
\hline
\end{tabular}

${ }^{\text {a }}$ At $100 \mathrm{~cm}$

${ }^{\mathrm{b}}$ Includes $\mathrm{P}_{\text {org-U }}$ 
1111 Fig. 1

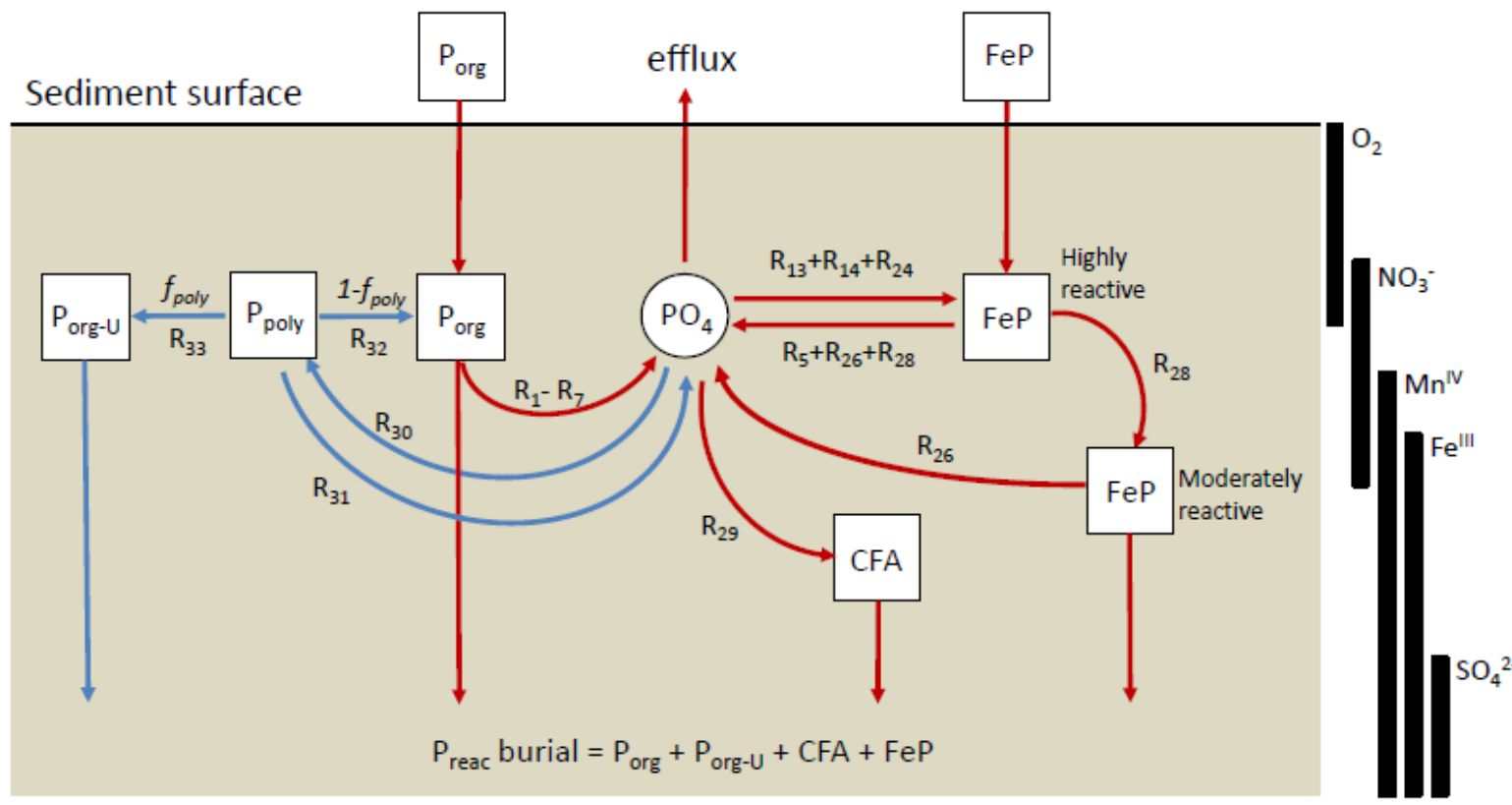

1112

1113 
1114 Fig. 2.
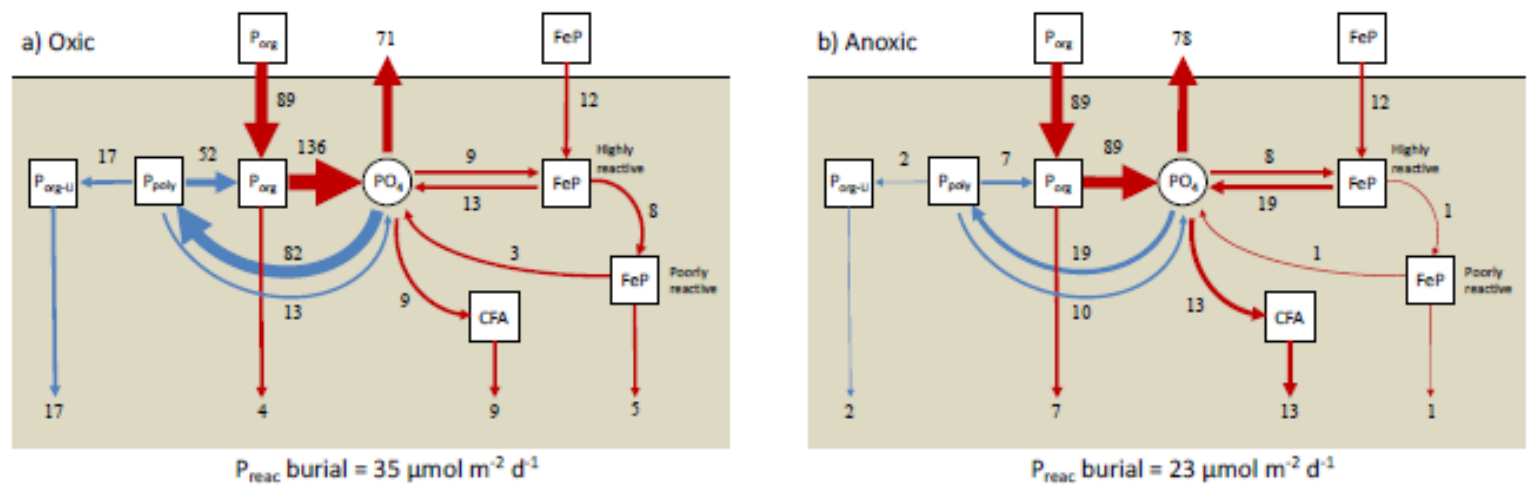

1115

1116 
1117 Fig. 3

Figure

Modern shelf
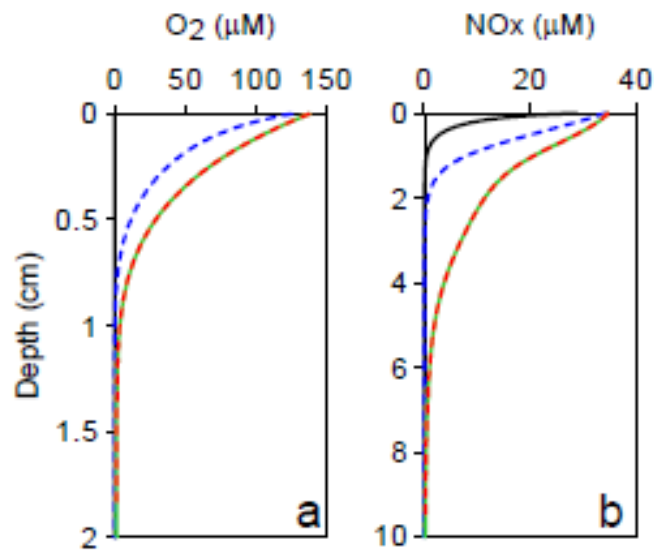

$\mathrm{PO}_{4}{ }^{3-}(\mu \mathrm{M})$

Corg (wt.\%)
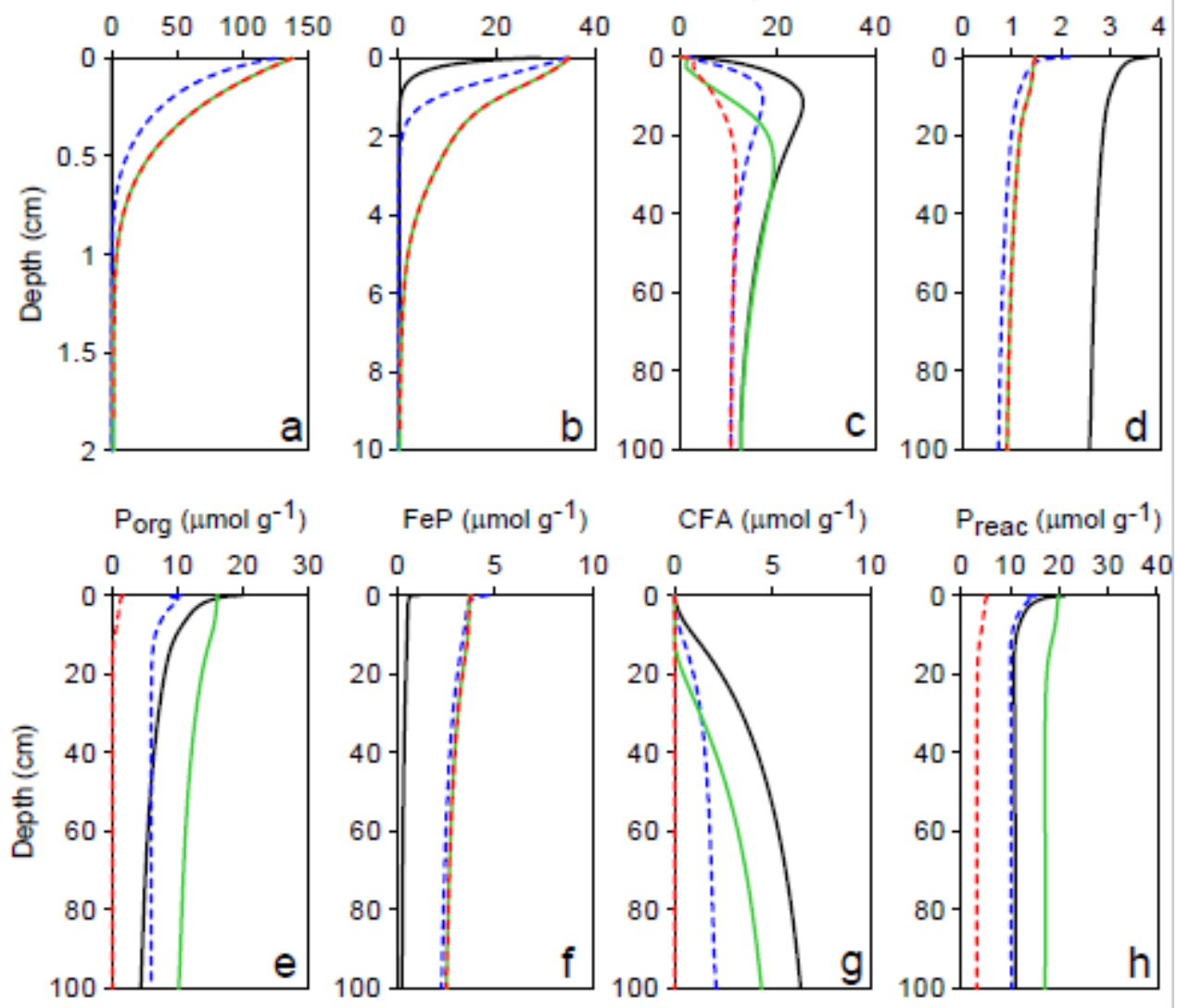

1118

Oxic

Anoxic

---- Oxic, fauna, microbial P pump off

---- Oxic, no fauna, microbial $P$ pump on

1119 

Fig. 4

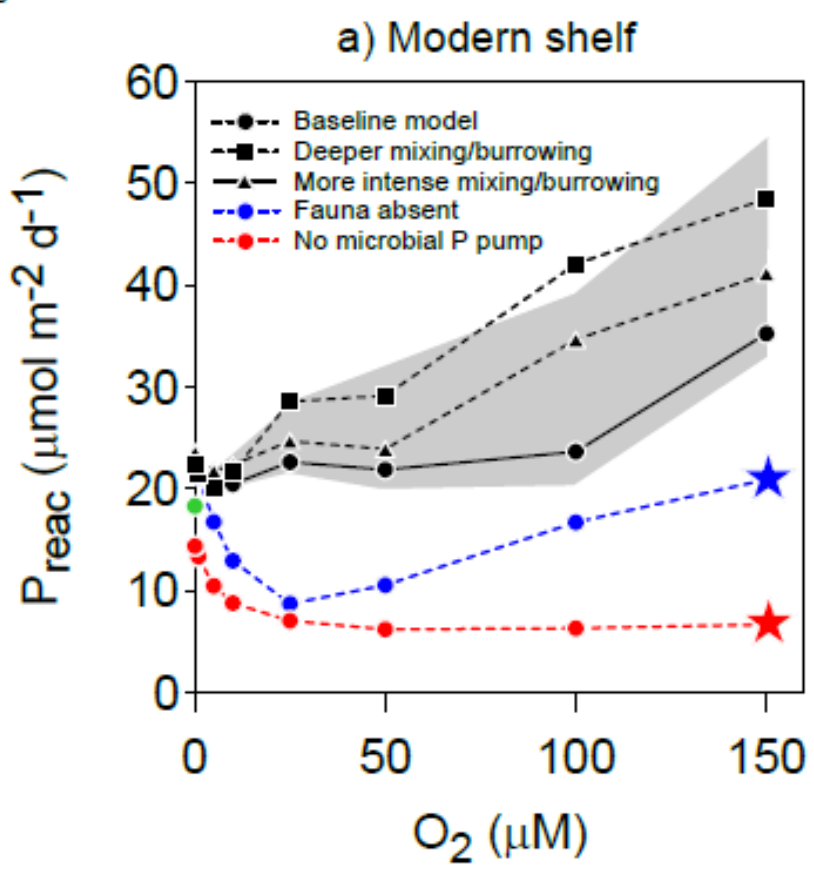

b) Early Paleozoic

1121

1122 
1123 Fig. 5

Figure Rate $\left(\log _{10} \mathrm{mmol} \mathrm{cm}-3 \mathrm{yr}^{-1}\right)$

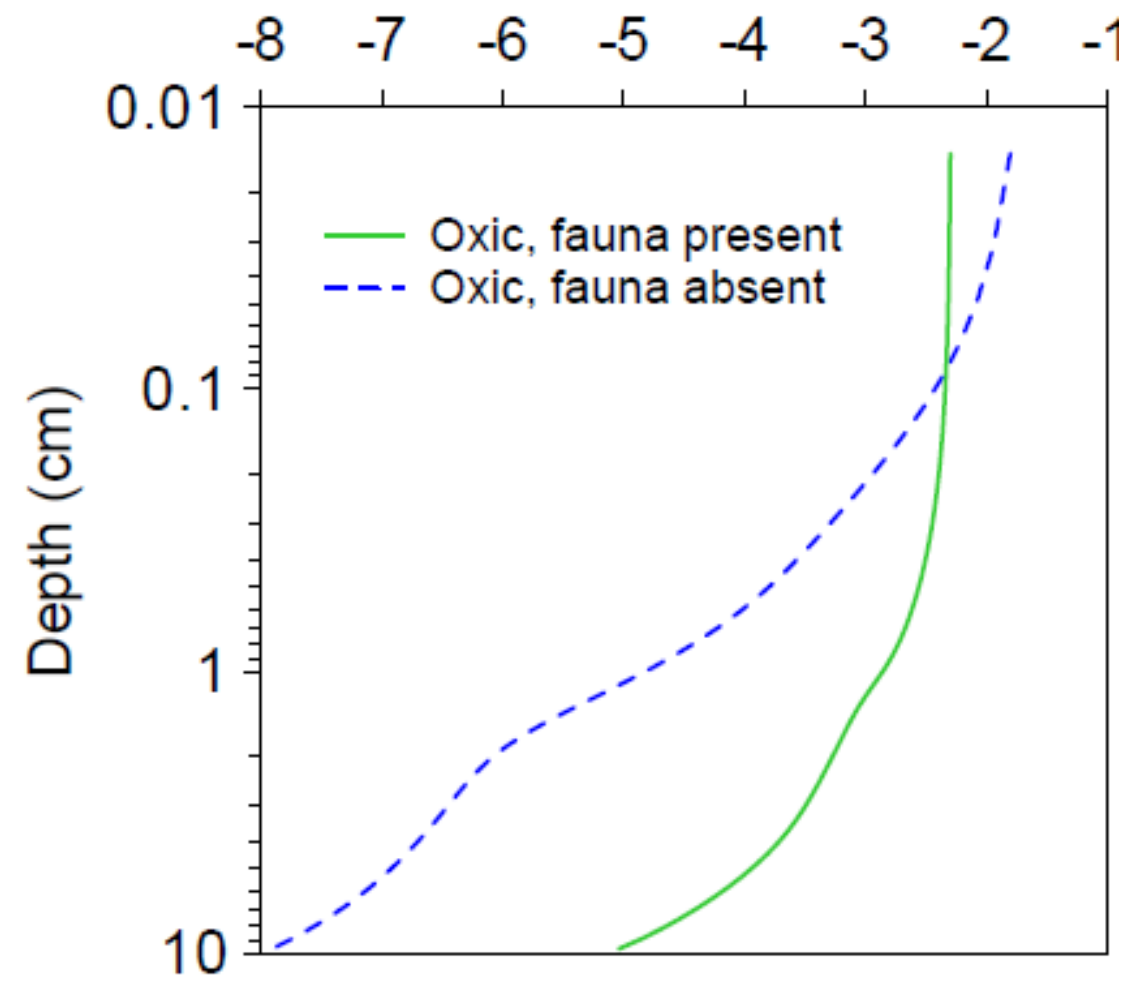

